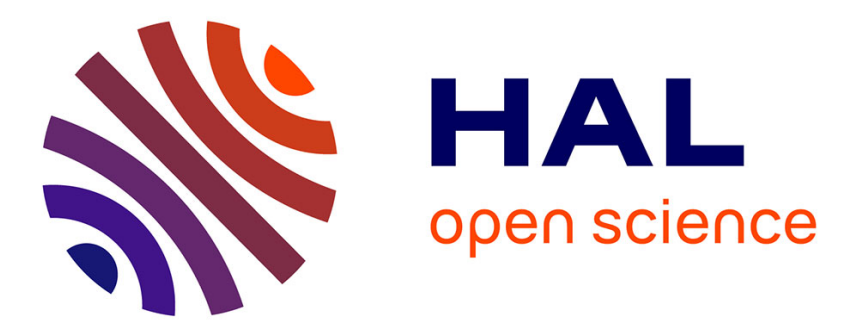

\title{
How do inequalities affect the natural interest rate, and how do they impact monetary policy? Comparing Germany, Japan and the US \\ Mariam Camarero, Gilles Dufrénot, Cecilio Tamarit
}

\section{- To cite this version:}

Mariam Camarero, Gilles Dufrénot, Cecilio Tamarit. How do inequalities affect the natural interest rate, and how do they impact monetary policy? Comparing Germany, Japan and the US. 2021. halshs-03191667

\author{
HAL Id: halshs-03191667 \\ https://shs.hal.science/halshs-03191667
}

Preprint submitted on 7 Apr 2021

HAL is a multi-disciplinary open access archive for the deposit and dissemination of scientific research documents, whether they are published or not. The documents may come from teaching and research institutions in France or abroad, or from public or private research centers.
L'archive ouverte pluridisciplinaire HAL, est destinée au dépôt et à la diffusion de documents scientifiques de niveau recherche, publiés ou non, émanant des établissements d'enseignement et de recherche français ou étrangers, des laboratoires publics ou privés. 


\section{amse}

école d'économie d'aix-marseille

aix-marseille school of economics

\section{Working Papers / Documents de travail}

How do inequalities affect the natural interest rate, and how do they impact monetary policy? Comparing Germany, Japan and the US 


\title{
How do inequalities affect the natural interest rate, and how do they impact monetary policy? Comparing Germany, Japan and the US *
}

\author{
Mariam Camarero †, Gilles Dufrénot ałand Cecilio Tamarit $\S$
}

\begin{abstract}
In this paper we analyze how growing income/wealth inequality and the functional income distribution inequality have contributed to the sustained low potential growth observed in the industrialized economies during the last two decades, a period that includes the Great Recession (GR). Growing inequality may constitute a drawback for the recovery of these economies, especially after the Great Pandemic (GP). To this aim, we modify the semi-structural model originally proposed by Holston, Laubach and William, by considering the effects of several types of inequalities. We jointly estimate potential growth and the natural interest rates. We show that the latter can substantially modify the time path of the real interest rate that prevails when economies are at full strength and inflation is stable.
\end{abstract}

Keywords: Potential growth; Inequality; Natural interest rate; G7; State-space model JEL classification: E62, E52, E21, C32

${ }^{*}$ Cecilio Tamarit and Mariam Camarero acknowledge the public funding from the ERDF and AEI-Spanish Ministry of Economy and Competitiveness (ECO2017-83255-C3-3-P project), the Valencian regional government (Generalitat Valenciana-PROMETEO 2018/102 project) and the European Commission (project 611032-EPP-12019-1-ES-EPPJMO-CoE). Gilles Dufrénot acknowledges financial support by French National Research Agency Grants ANR-17-EURE-0020. The European Commission support does not constitute an endorsement of the contents which reflects the views only of the authors. All remaining errors are ours.

${ }^{+}$University Jaume I and INTECO, Department of Economics, Campus de Riu Sec, E-12080 Castellón (Spain).

ła Corresponding author:Aix-Marseille Univ, CNRS, AMSE, Marseille, France and CEPII, email: gilles.dufrenot@univ-amu.fr

§University of València and INTECO, Department of Applied Economics II, PO Box 22006 E-46071 Valencia, Spain. 


\section{Introduction}

After three decades of increasing inequality in most advanced economies, and with the entailed risk of creating social division acting as potential catalyst for populism, discussion on the effects of inequality on the economic prosperity of societies has regained momentum. Although most of the decline in equality was concentrated in the 1980s and 1990s and the change has been greater in certain countries such as the US, the overall trend in developed countries has been towards more inequality, reflecting increasing polarisation in wages (after tax and transfers) within the top income deciles compared with the middle and especially the bottom deciles.

Although there are many different causes that explain this evolution, two of them are particularly salient (Baldwin, 2019): technological changes and economic globalisation. On the one hand, technological changes have favoured a surge of the earnings linked to highly educated workers, leading to a education wage premium ${ }^{1}$. On the other hand, economic globalisation has affected the distribution of wealth in advanced economies by reducing the demand for less qualified workers who compete directly (via relocation) or indirectly (via imports) with workers from emerging economies. At the same time, economic globalisation has increased market size and thereby wages of more highly qualified workers as their productivity has grown. This process of growing inequality has evolved in parallel with a declining trend in output growth and real interest rates over the past thirty years in many advanced economies, reflecting a process coined as secular stagnation. ${ }^{2}$ Therefore, low interest rates would be reflecting a persistent excess of desired savings over investment leading to a period of secular stagnation.

Summers (2013) stressed, for the case of the US, how changes in income distribution have benefited less to agents with the strongest marginal propensity to consume. Indeed, as wage inequality widened, high-income households with both, higher wages and capital gains, showed a clear bias to save above the average, challenging future growth rates. These two phenomena, rising inequality and chronic weakness of demand, are related. In particular, rising inequality transfers income from low-saving households in the bottom and middle of the income distribution to higher saving households at the top. All else equal, this redistribution away from low to high-saving households

\footnotetext{
${ }^{1}$ See Bartscher et al. (2020) for a recent survey.

${ }^{2}$ Recently, the same phenomenon has been recast as a fall in the economy's "natural" or "neutral" rate of interest, an unobserved theoretical interest rate that is supposed to balance desired savings and planned investment when output is equal to its potential.
} 
reduces consumption spending and demand growth, being the root cause of this rising inequality the growing wedge between productivity and hourly-wage pay to US workers. Moreover, as corporate profits also grew during the 2000s, they shifted from being net borrowers from the rest of the economy to being net lenders of funds. The effect on demand of this rise in inequality and savings was concealed by an increase in debt among the lowest-income households, which sustained demand artificially before the crisis. However, the debt slowdown triggered by the GR revealed the existence of an underlying secular stagnation. In principle, inequality should not be a problem for growth. The reduced consumption stemming from this redistribution should translate into higher savings, lower interest rates, and more business investment in plants and equipment. Thus, this interest rate adjustment would ensure that the reduced consumption spending that follows the upward redistribution of income is matched by an increase in investment spending, and hence does not constitute a drag on growth in aggregate demand. However, the economy's ability to seamlessly translate lower consumption (or higher savings) into higher investment spending will be potentially blocked by the zero lower bound (ZLB) on interest rates. When the effective lower bound is binding, further increases in savings will instead show up as unused capacity and output losses rather than interest rates reductions. Again, this decline in demand growth will show up in data as either a slowdown in overall growth, or a pronounced decline in the natural interest rate.

This paper proposes new estimates of the natural interest rate of three industrialized countries (the United States, Japan and Germany), taking into account the effects of several types of inequalities on output and inflation (income/wealth individual inequalities, functional income distribution due to structural factors such as gender gap and the lagging of wages behind productivity, the percentage of low-paid workers, inequalities due to family labour status). The empirical framework is a modified Laubach and Williams (2003)'s model (henceforth LW) where the transmission of inequality on output and inflation operates both from demand-side and supply-side channels. We find that differences in the estimates of the natural interest rate can be large. We interpret this finding as a problem of omitted variable bias and show that the inclusion of inequality variables in the AD and AS equation modifies significantly the usual coefficients of a standard LW model. Specifically, the output-gap reaction to the interest rate gap changes hugely, as well as the coefficient measuring the inflation/output link. 
We depart from previous literature in that we consider shadow interest rates, rather than the observed policy rate. This is necessary to take into consideration the changing nature of monetary policy over the period under investigation (2000 - 2019), from conventional to unconventional measures, without introducing a structural break in the model due to the zero lower bound constraint. By avoiding "kinked" aggregate demand function (which occurs in a model with ZLB), we also avoid the possibility of having multiple equilibria. So our model has just one steady state that is observed when the shadow rate and the natural rate coincide.

Recent literature distinguishes between partial equilibrium and general equilibrium effects of inequality on aggregate demand and supply (Eggertsson et al., 2019). For instance, partial equilibrium effects are measured by the effect of income inequality on aggregate demand through differences in the propensity to consume. It also happens when one considers the effects of changing prices of the financial assets leading to unequal share of these assets among individuals. In the case of aggregate supply, it can also be measured when unequal wages affect prices through the impact on labour productivity. Such effects are captured in our modified models by the coefficients of the inequality variables. The partial equilibrium effects get multiplied by the general equilibrium effects which are caused by economic policies. We accordingly also modify the original state equation in LW model in which the natural rate is determined by potential GDP and unobservable variables. This relationship can be interpreted as a Golden rule which determined the optimal level of saving in an economy. In the tradition of Cass-Koopman models, it can also be interpreted as a Golden Utility rule with the interest rate being a function of potential growth and of the subjective rate of time preference. As explained below, this rate is likely to vary across individuals in society, especially if the intertemporal trade-offs in consumption imply redistribution amongst the individuals.

The natural interest rate is usually considered a benchmark for monetary policy and, depending on whether the deviation from the policy rate is positive or not, it gives an indication of the stance of monetary policy. The question of the link between monetary policy and inequalities is often investigated from the former to the latter. Indeed, the redistributive effects of monetary policy are most often understood through its effects on inflation, growth, income and employment. In this paper, we are interested in the reverse causality. By considering the natural interest rate as an attractor of the short-term rate of 
monetary policy, we ask ourselves how inequalities contribute to its determination. For instance, greater inequalities could be associated with higher savings, therefore implying stronger downward pressure on the natural rate of interest. Similarly, wage inequalities, the concentration of wealth and earnings could contribute to reduce desired investment and aggregate demand, thereby preventing an economy to reach a full employment and full capacity growth rate. In this case, the natural rate would be too low. Similarly, if inequality leads to weak economic growth, it can lead to a downward trend in real interest rates. Inequalities, through different channels, can thus appear as advanced indicators of the determinants of the natural rate, notably savings and investment. Indicators of inequalities can therefore be used by central banks to set their interest rate, because they have an influence on the variables that central bankers look at to set their policy rate, i.e. inflation and growth. To our knowledge, no study has been conducted so far that includes inequality as a determinant of the real interest rate. We conduct a comparative analysis of three countries where inequality has increased over the last decade and which have experienced different performances in terms of growth and inflation: The United States, Germany and Japan.

The remainder of the paper is organized as follows: in Section 2 we briefly review the literature linking inequality, growth, and the natural interest rate. Section 3 presents our modified LW model. Section 4 presents a summary of the econometric methodology, while Sections 5 and 6 describe the data and our results. In Section 7, we investigate some implications for the monetary authorities' reaction function. Finally, Section 8 concludes.

\section{Inequality, growth and natural interest rate: brief literature review}

According to the secular stagnation view, weak aggregate demand and a lack of productive investment opportunities have shifted the economy into a state of persistent stagnation at very low - if not negative - real interest rates. This hypothesis, posited initially by Hansen (1939), was led to oblivion after the massive increase in government spending and the baby boom subsequent to World War II. However, the persistence of the slump affecting Japan since the early 1990s, as well as the slow recoveries experienced by the US and the Euro area in the aftermath of the 2008 Great Recession (GR) have revived its interest as it may explain the creation of a vicious circle preventing a swift return to normal after the GR. A worry that can be enhanced after the current Great Pandemic (GP)(Baldwin 
and Weder di Mauro, 2020; Baldwin, 2020). Dampened aggregate demand causes low investment, which in turn reduces the economy's potential growth rate through a reduction and deterioration of the quality of physical and human capital. Under these circumstances, the low interest rate environment may also generate asset bubbles (i.e. housing market or dot com crises) that may have uncovered the underlying decrease in potential economic growth (Summers, 2013). Finally, the secular stagnation hypothesis can be of particular relevance as central banks might face difficulties in setting the appropriate nominal interest rate policy when the zero lower bound (ZLB) is binding, creating a liquidity trap.

Summers (2013) pioneered a debate over the factors that might have contributed to the decline of the natural interest rate. Some potential factors can be transitory, such as post-crisis private debt deleveraging (Rogoff, 2015), a temporary savings glut (Bernanke, 2015), or higher regulatory burdens for firms and households (Taylor, 2016). However, there are also arguments in favor that the low interest rates are led by persistent factors connected to a secular stagnation, causing a long-lasting decline in profitable investment opportunities and high global savings rates. Desired investment can be connected to expected poor long-term productivity growth. Although several authors take a positive view about future progress in productivity derived from the digital revolution ${ }^{3}$, others are more pessimistic ${ }^{4}$ and enumerate a number of factors, such as the stagnation produced by a declining quality of human capital, the effects of globalization, ageing, environmental issues and increasing public and private debt, that would be depriving resources from investment. At the same time, technical progress seems to have reduced the relative prices of capital goods while digital innovations seem not having yet complemented the available skills of workers in terms of higher productivity. Concurrently, other authors (Rachel and Smith, 2015) stressed that desired savings have probably increased due to demographic forces but also to higher inequality within countries ${ }^{5}$. Interestingly, although the seminal studies on secular stagnation remarked the pivotal role played by income inequality as explanatory variable, empirical research testing the importance of this variable is scarce, to say the least.

\footnotetext{
${ }^{3}$ Such as Brynjolfsson and McAfee (2014).

${ }^{4}$ See Gordon $(2012,2016)$.

${ }^{5}$ Rachel and Smith (2015) estimate that the effect of rising inequality on interest rates fall has a par influence compared with any other single driver they survey. This fall in interest rates is driven both by global and country-specific factors. Given that the US economy has seen a larger concentration of income at the top of the distribution than other advanced countries, the effect of inequality on the pace of aggregate demand growth (and hence interest rates) is likely larger as well.
} 
Eggertsson et al. (2019) explain secular stagnation through a New Keynesian model where the importance of inequality, among other structural factors, is made explicit. In their model, unemployment is high for an indefinite amount of time due to a permanent drop in the natural rate of interest. They consider a simple overlapping generation model where households go through three stages of life: young, middle aged and old, and income is largely concentrated within the middle generation. Assuming that borrowing by the young is constrained, the steady-state real interest rate is no longer determined solely by households' discount factor but by the relative supply of savings and demand for loans. Interestingly, their results show that four factors, namely, a slowdown in population growth, a tightening of borrowing limits, a fall in the relative price of investment goods and an increase in income inequality, either across or within generations, may generate a permanent negative real interest rate. Other recent contributions that explain permanent deflation in a ZLB environment are Benigno and Fornaro (2018) and Fornaro and Wolf (2020) where the ZLB is binding due to self-fulfilling expectations in a complementing way to the fundamental factors. This model, especially designed to explain the economic consequences of Covid-19, can be easily modified to include inequality as driver of a stagnation trap. Let us assume that an increase in inequality creates first, a demand slump. In this case, lower wages induce lower demand that increases financial constraints to invest by firms and also constraints the capacity to invest in human capital, that is, education and training, in poorer people (that will have negative effects on productivity). As a result, a demand/supply doom loop is generated that creates a poverty/inequality trap. Initial pessimistic expectations of weak growth thus become self-fulfilling. Importantly, this self-fulfilling feedback loop can take place only if the fundamentals of the economy are sufficiently weak. Restoring full employment through monetary stimulus might not be that easy as interest rates are very low because of the effective lower bound constraint. As a consequence, a more effective way to reverse the supply-demand doom loop is through appropriate fiscal policy interventions. This can be made via a rise in subsidies (transfers), increasing public investment or credit provision to level out income for poorer population. These policies would increase consumption, health and education levels, soaring both demand and productivity, and triggering a virtuous loop. Under this framework where multiple equilibria are possible, only sufficiently aggressive fiscal interventions can rule out stagnation traps, changing agent's expectations and shifting the economy from bad to 
good steady state equilibria. ${ }^{6}$

Other modern micro-founded macroeconomic models based on life-cycle models, like overlapping generation models with three periods of life: young, worker and retired, usually depart from the representative agent and complete markets assumptions. Under these conditions Ricardian Equivalence does not hold, and government transfer policies affect the equilibrium allocations through several distinct channels.

First, redistribution across time through intertemporal transfers matters when peoples' planning horizons are finite. The reason is intuitive: with finite planning horizon, agents currently alive expect to shoulder only a part of the financing burden that comes with today's transfer; the rest is to be serviced by future generations. Such transfers thus affect agents' wealth and their consumption and saving plans (Blanchard, 1985).

Second, transfers across agents can affect aggregate consumption and saving (and hence the interest rate) if agents have different marginal propensities to consume (MPCs). Differences in MPCs could arise because of several distinct features of the economic environment. They could be a result of un-insurable risks and binding borrowing constraints, as in Aiyagari (1994) and Oh and Reis (2012). They could emerge because some agents have little to no liquid wealth, preventing them from adjusting their consumption, as in Kaplan et al. (2014). Another reason may be the life-cycle: propensity to consume may differ between workers and retirees, as in Gertler (1999), or may vary with age as in Eggertsson et al. (2019).

The third way in which government policy affects interest rates is what may be called a precautionary saving channel. One facet of this channel is that government policies can directly reduce the risks faced by the agents. The mechanism is close to the one analyzed by Engen and Gruber (2001). Under imperfect insurance, agents who face some idiosyncratic risks - for example those related to health or unemployment - attempt to self-insure through saving. This precautionary saving motive acts to push the interest rate below the rate that would prevail in a complete markets economy (where all risks are insurable and so do not affect the agents' behavior). Government policies such as

\footnotetext{
${ }^{6}$ Note that in Eggertsson et al. (2019) they find a parallel result for monetary policy: an inflation target which is below what is required to keep permanently negative natural interest rates levels has no effect in this context of secular stagnation. This result formalises what Krugman (2014) defined as the timidity trap. Moreover, in a secular stagnation environment, there are strong limitations of forward guidance with nominal interest rates, as the capacity to manipulate expectations under ZLB is limited.
} 
social insurance will affect the importance of precautionary saving: a stronger social safety net or higher unemployment and disability benefits curtail the associated risks, curbing the desire to save. Conversely, lack of social insurance means that agents need to rely on their own resources when experiencing hardship, making personal saving a priority.

Inequality is currently a hot topic dominating the political agenda in various countries, many of which are still characterized by a sluggish recovery and continuing high unemployment rates. The possible channels through which inequality might negatively affect economic growth can be summarized as follows (García-Penalosa, 2007): first, poor people has often less access to health care, which lessens the human capital accumulation and may diminish growth overtime (Alesina and Perotti, 1996); second, increasing inequality might prevent poorer households from receiving a proper education level, which renders labour productivity lower (Stiglitz, 2012); third, less equal societies yield both lower domestic social stability and institutional quality, which may act as a less efficient shock absorber and dismiss foreign investment (Rodrik, 1999; Acemoglu et al., 2004).

However, higher inequality can also have positive effects on economic growth and therefore, this is an open question that deserves further empirical analysis.

\section{A modified HLW model with inequality variables}

Laubach and Williams (2003) model, recently re-applied internationally by Holston et al. (2017), that we will refer to as HLW model, is one of the most commonly used approaches to estimate the natural interest rate. In particular, it consists of a structural framework that takes into account movements in inflation, output and the interest rate. The philosophy of the LW method is that the natural rate of interest is an endogenous object determined in general equilibrium, and as such it will depend on a host of socio-economic forces, such as trends in preferences, technology, demography, policies and policy frameworks. It is impossible to know and measure all the relevant factors. To reflect the dependence on growth and on a range of (possibly unknown) other factors, the LW model assumes that the natural rate depends on the estimated trend growth rate of potential output and a time-varying unobserved component that captures the effects of other unspecified influences. The model further assumes that both the growth rate and the unobserved component are random walk processes. In short, the LW model views the natural rate as 
the sum of two independent random walks. To achieve identification, LW add two further equations to the model. First, they specify a simple reduced-form equation relating output gap to its own lags, a moving average of the lagged real funds rate gap, and a serially uncorrelated error. Second, LW add the reduced-form Phillips curve to the model, linking current inflation to lagged inflation and the output gap. The system above can be written in a state-space form, and the Kalman Filter can be used to estimate the unobservable states.

We modify the HLW model by considering two types of inequalities. First, some inequalities are related to personal income and wealth distributions. They affect aggregate demand through the saving/investment equilibrium. Second, inequalities related to factor income distribution affect aggregate supply through the wage/price dynamics.

For the demand-side channel, our equation is a dynamic empirical counterpart of a theoretical model recently proposed by Calvert Jump (2018) to uncover the effects of income inequality on aggregate demand in a simple manner. The author's model relies on the standard aggregate saving and investment equation (as functions of respectively income and real interest rate) and on the assumption of log-normal distribution of income. An expression is derived where the expected level of income depends upon the coefficient of variations of income. In our empirical equation, income and interest rates are expressed as deviation to their long-term value. Moreover, the coefficient of variation of income is assumed to depend on and to be correlated to inequality indicators, such as differences between the bottom and top end of income distribution (income disparities), net wealth inequalities and GINI coefficients. Income inequalities affect aggregate demand through several transmission mechanisms: imperfect financial markets (imperfect pooling of rate of return, self-financing and borrowing constraints or idiosyncratic uncertainty) and different demand elasticities between rich and poor consumers.

For the supply-side channel, inequality indicators are usually related to factors that affect labour productivity, human capital investment and the functional distribution of income. Examples of such factors are gender inequalities and the differentials between income share and productivity. There is some empirical evidence in the literature that gender pay gap and gender labour market participation gap can hurt productivity (Cuberes and Teignier, 2012). Since labor productivity is one of the determinants of potential growth, this can in turn affect the natural growth rate. Income distribution 
can also be related to long-term economic growth in relation to rate of profit and the wage share out of total income. Since the last three decades, the distribution of income has been disrupted by a disconnection between the growth rate of unit labor costs (or the wage share) and labor productivity, as argued by Faggio et al. (2007), Furman and Orszag (2018) and OECD (2018). In Appendix A, we propose a simple stylized theoretical model showing how taking into account the wage share modifies the standard AS curve.

The AD and AS modified equations considered in this paper are reduced-form equations which aim at capturing, empirically, some potential links between inequality and output/inflation and see whether such correlation affects or not the dynamic path of potential growth and the natural interest rate in the G7 countries.

\subsection{Modified AD and AS equations}

The AD equation is as follows:

$$
\widetilde{y_{t}}=a_{y}(L) \widetilde{y}_{t-1}+a_{r}(L)\left(r_{t-1}-r_{t-1}^{*}\right)+A_{Z}(L) Z_{t}+a_{3}+\sigma_{\widetilde{y}} \epsilon_{t}^{\widetilde{y}}, \quad \epsilon_{t}^{\widetilde{y}} \approx N(0,1) .
$$

where $\widetilde{y_{t}}=100 *\left(y_{t}-y_{t}^{*}\right)$ is the output-gap, $y_{t}=\ln ($ realGDP $)$ and $y_{t}^{*}$ is logarithmic potential GDP. $r_{t}$ is the real short-term interest rate and $r_{t}^{*}$ is the natural interest rate. We augment this equation with some exogenous inequality variables, in the vector $Z_{t}$, that affect aggregate demand: Gini index which measures income inequality at a macro level, Palma ratio as an indicator of income disparities and wealth inequality. $a_{y}(L), a_{r}(L), A_{Z}(L)$ are lag polynomials. In the HLW model, $A_{Z}(L)=\mathbf{0}$. If inequalities have an impact on the estimate of the output-gap, their model suffers from an omitted variable bias. The size of the bias depends on the correlation between inequality and $\left(r_{t-1}-r_{t-1}^{*}\right)$, which is a proxy for the stance of monetary policy. Some channels by which monetary policy affects inequalities are inflation tax channel, savings redistribution channel, interest rate exposure channel, earnings heterogeneity channel, and income composition channel (Amaral, 2017). Ignoring their potential effect could therefore lead to over-estimate or under-estimate the stance of monetary policy on the business cycle.

The aggregate supply equation is as follows:

$$
\pi_{t}=b_{\pi}(L) \pi_{t-1}+b_{y}(L) \widetilde{y}_{t-1}+B_{\kappa}(L) \kappa_{t}+B_{W}(L) W_{t}+b_{3}+\sigma_{\pi} \epsilon^{\pi}, \quad \epsilon^{\pi} \approx N(0,1) .
$$


where $\pi_{t}$ is core inflation at time $t, \kappa_{t}$ is a vector which consist of two variables: core import prices and crude oil prices measured as deviations from core inflation, $W_{t}$ is a vector of functional inequality variables: gender gap, labour income share growth minus labour productivity and the percentage of low paid full-time employees. $b_{\pi}(L), b_{y}(L), B_{\kappa}(L), B_{W}(L)$ are lag polynomials. In HLW model, $B_{W}(L)=\mathbf{0}$. Strong correlation between $W_{t}$ and $\widetilde{y}_{t-1}$ could lead to an omitted bias problem. There is overwhelming empirical evidence in the literature of falling share of wages in GDP stemming from a slowdown in average real wage growth relative to productivity growth, since the beginning 1990s. At the same time, increases in wage inequality have been observed, reflected by gender gaps (in pay or labour market participation) and low and middle wages lagging behind average growth. Since such inequalities harm labor productivity, they are likely to slow potential growth and thereby change the dynamics of the natural interest rate.

\subsection{Unobserved state variables}

In addition to Equations (1) and (2), we also consider the following state (unobserved variables):

$$
\begin{gathered}
r_{t}^{*}=c_{1} g_{t-1}+c_{3} s_{t}, \\
g_{t}=\delta_{g} g_{t-1}+\bar{g}+\sigma_{g} \epsilon_{t}^{g}, \quad \epsilon_{t}^{g} \approx N(0,1), \\
y_{t}^{*}=y_{t-1}^{*}+g_{t-1}+\sigma_{s} \epsilon_{t}^{y^{*}}, \quad \epsilon_{t}^{y^{*}} \approx N(0,1), \\
s_{t}=d_{s} s_{t-1}+\sigma_{s} \epsilon_{t}^{s}, \quad \epsilon_{t}^{s} \approx N(0,1) .
\end{gathered}
$$

The natural interest rate, $r_{t}^{*}$, is driven by potential growth, $g_{t}$, and other unobserved determinant, $s_{t}$ (for instance demography). Potential growth follows a mean reverting process ( $\bar{g}$ is potential growth average), thereby implying that potential growth, $y_{t}^{*}$, is $I(1)$. $c_{1}, \delta_{g}, \bar{g}, d_{s}$ are real numbers.

There are several explanations for Equation (3). First, $r^{*}$ can be interpreted as a long-term interest rate. Using Wicksell's interpretation, potential growth $g^{*}$ determines the marginal rate of return on capital. This is an "attractor" towards which the long-term equilibrium interest rate converges. It is therefore an interest rate which is determined by real forces (as opposed to monetary or financial forces). This interpretation is taken up by neoclassical growth models. Equation (3) can be interpreted as a modified golden rule linking the equilibrium interest rate to the marginal productivity of capital and to a set of other 
variables influencing medium/long-term growth (demography, level of public spending, etc.). In this case, the coefficient $c_{1}$ is expected to carry a positive sign.

A second explanation is that $r^{*}$ is a short-term interest rate. This is the interpretation, for example, of the New Keynesian macroeconomics models. It is the real interest rate observed when prices are perfectly flexible. A deviation between the observed short-term real rate and $r^{*}$ thus gives an idea of the degree of price (and wage) rigidity in the economy. More importantly, any deviation can explain inflationary or deflationary pressures. The equilibrium rate is not fixed, but can fluctuate under the influence of various shocks related to supply and demand factors. In this approach, the natural interest rate is used to guide central banks in setting their policy rate to adjust the general price level so that the observed real rate converges towards the natural rate.

A third approach focuses on the role of finance. Contrary to the two previous interpretations, Neo-Cambridgean economists explain that the natural interest rate is not regulated by production relationships, but by distribution relationships. Historically, we have observed a divergence between the rapid growth of financial rents and a secular decline in market interest rates (nominal and real). The boom in financial markets has also led to a squeeze of risk premia while amplifying movements in structural growth (particularly because the financial cycle has long duration). In this context, if the financial cycle is a key factor of structural growth, we should expect to find a negative estimate of $c_{1}$.

\section{Econometric methodology}

To keep the model simple and avoid over-fitting (too many estimated parameters), we assume that all lag polynomials are of order 1 , except $a_{r}(L), b_{\pi}(L), b_{y}(L)$ which are of order zero.

For the remainder parameters, the model is first rewritten as a state-space model. Kalman

filter and maximum likelihood are used to obtain the estimates. In Appendix B, we present the details of the state space form of the model. 
The general state-space representation of the model is as follows:

$$
\begin{array}{r}
X_{t}=A X_{t-1}+\zeta_{t}+F_{t} \eta_{t}: \text { state equation } \\
Y_{t}=\mu_{t}+C_{t}^{T} X_{t}+G_{t} V_{t}: \text { measurement equation }
\end{array}
$$

$X_{t}$ is the vector of $k_{1}=8$ state variables (unobserved), $Y_{t}$ is the vector of $k_{2}=2$ observed variables, $\mathrm{A}$ is a $k_{1} \times k_{1}$ matrix, $\zeta_{t}$ is a $k_{1} \times 1$ vector of deterministic terms, $\eta_{t}$ is a $r_{1} \times 1$ vector of residuals, $F_{t}$ is a $k_{1} \times r_{1}$ matrix, $G_{t}$ is a $k_{2} \times r_{2}$ matrix, $\mu_{t}$ is the product of a $k_{2} \times n \operatorname{expl}$ matrix of coefficients by a vector of nexpl explanatory variables. $C_{t}$ is a matrix of dimension $k_{2} \times k_{1}\left(C_{t}^{T}\right.$ is the transpose of $\left.\mathrm{C}\right)$ and $V_{t}$ is a vector of $r_{2}$ residual terms.

More specifically, we have

- State variables : $y_{t}^{*}, y_{t-1}^{*}, y_{t-2}^{*}, r_{t}^{*}, r_{t-1}^{*}, g_{t}, g_{t-1}, s_{t}$,

- Observed variables : $\pi_{t}, y_{t}$,

- deterministic term: $\bar{g}$,

- $\mu_{t}$ is the product of the exogenous variables (including the exogenous variables) and their loading matrix.

We consider a simplified model by assuming that

$$
a_{y}(L) \widetilde{y}_{t-1}=a_{y}^{0} \widetilde{y}_{t-1}+a_{y}^{1} \widetilde{y}_{t-2}, \quad a_{r}(L)\left(r_{t-1}-r_{t-1}^{*}\right)=\frac{a_{r}}{2} \sum_{j=1}^{2}\left(r_{t-j}-r_{t-j}^{*}\right)
$$

We further consider 1 lag for the variables in the vectors $Z, W$ and $\kappa$, and we define $b_{\pi}(L)=$ $b_{2}, b_{y}(L)=b_{1}, \delta_{g}=d_{s}=1, \bar{g}=0$.

We compare estimates of the natural interest rate, and potential growth, from the models, with and without inequality variables.

\section{Data}

We present estimations using quarterly data from 2000Q1 to $2019 Q 4$ for three countries: Germany, Japan and the United States. Table 1 in the appendix describes the variables, their definition and the source of data. 
Regarding the data, we provide one novelty. We use nominal shadow rates instead of nominal observed interest rates to compute the real interest rates. This allows us to avoid nonlinearities in the model due to the zero-lower bound constraint. This permits a better comparison with the natural interest rate since the shadow rate measure the stance of monetary policy due to quantitative easing policies. Using shadow rates also avoids introducing a second variable (like central bank's balance sheets or assets) from 2009 onward. Several methodologies have been proposed in the literature to estimate shadow interest rates (Cynthia Fan Dora Xia, 2016; Wu and Zhang, 2019; Krippner, 2015). Data are taken from the estimates of the Central Bank of New Zealand based (https://www.rbnz.govt.nz/research-and-publications/research-programme/ additional-research/measures-of-the-stance-of-united-states-monetary-policy).

Several inequality variables are annual. To construct their quarterly equivalent, we simply replicate, for each quarter, the annual value.

\section{Data and Empirical Results}

\subsection{Data}

We present estimations using quarterly data from $2000 Q 1$ to $2019 Q 4$ for three countries: Germany, Japan and the United States. Table 1 in the appendix describes the variables, their definition and the source of data.

Regarding the data, we provide one novelty. We use nominal shadow rates instead of nominal observed interest rates to compute the real interest rates. This allows us to avoid nonlinearities in the model due to the zero-lower bound constraint. This permits a better comparison with the natural interest rate since the shadow rate measure the stance of monetary policy due to quantitative easing policies. Using shadow rates also avoids introducing a second variable (like central bank's balance sheets or assets) from 2009 onward. Several methodologies have been proposed in the literature to estimate shadow interest rates (Cynthia Fan Dora Xia, 2016; Wu and Zhang, 2019; Krippner, 2015). Data are taken from the estimates of the Central Bank of New Zealand based (https://www.rbnz.govt.nz/research-and-publications/research-programme/ additional-research/measures-of-the-stance-of-united-states-monetary-policy). 
Several inequality variables are annual. To construct their quarterly equivalent, we simply replicate, for each quarter, the annual value.

\subsection{Results}

A quick look at the inequality indicators in the US, Germany and Japan suggests several comments. In Table 1 we report two indicators of income distribution (the Gini coefficient and the Palma ratio). We also report a structural inequality indicator referring to labor market inequality (the proportion of workers earning low wages, i.e. less than two-thirds of the median wage), as well as the gap between the growth rate of the wage share in income and the growth of labor productivity. Finally, we consider an indicator of wealth inequality.

Table 1: Average evolution of inequality indicators

\begin{tabular}{lcccc}
\hline USA & & & & \\
& $2001-2005$ & $2006-2010$ & $2011-2015$ & $2016-2019$ \\
\hline Gini coefficient & 0.3718 & 0.37977 & 0.39175 & 0.39181 \\
Palma ratio & 1.54519 & 1.753 & 1.77625 & 1.7652 \\
Low pay workers & 30.4012 & 32.726 & 32.517 & 33.1934 \\
Labor income & -2.9469 & -1.8481 & -0.63159 & -0.8985 \\
Wealth inequality & 2.2844 & 2.4615 & 2.4144 & 2.4168 \\
\hline JAPAN & \multicolumn{4}{c}{} \\
& $2001-2005$ & $2006-2010$ & $2011-2015$ & $2016-2019$ \\
\hline Gini coefficient & 0.3255 & 0.3337 & 0.3354 & 0.337 \\
Palma ratio & 1.2447 & 1.3447 & 1.28025 & 1.319 \\
Low pay workers & 2.3257 & 2.4385 & 2.3155 & 2.321 \\
Labor income & 0 & 0 & 0 & 0 \\
Wealth inequality & 1.8347 & 1.93544 & 1.847 & 1.82 \\
\hline GERMANY & \multicolumn{4}{c}{} \\
& $2001-2005$ & $2006-2010$ & $2011-2015$ & $2016-2019$ \\
\hline Gini coefficient & 0.2843 & 0.2892 & 0.291025 & 0.28909 \\
Palma ratio & 0.988 & 1.09505 & 0.954 & 1.0197 \\
Low pay workers & 9.0475 & 9.54 & 9.2515 & 9.2415 \\
Labor income & -2.5588 & -0.3598 & -0.553 & -0.62188 \\
Wealth inequality & 1.55 & 1.844 & 2.255 & 2.51031 \\
\hline
\end{tabular}

The table shows developments that have been widely documented in the literature on the rise of income and wealth inequality, i.e. the deterioration of the Gini and Palma indicators, as well as higher wealth inequalities on average across time. These evolutions go hand in hand with a deterioration of the structural indicators showing an increase in the 
proportion of poorly paid workers and a change in the share of wages lower than that of productivity. The literature has highlighted a multiplicity of causes for this phenomenon in the industrialized countries. For instance, globalization and the generalization of outsourcing and offshoring practices have led to an atomization of labor markets and an increase in precarious work (fixed-term contracts, temporary work, etc). This has been a factor of wage compression. In addition, technological progress (automation, increasing role of digital technology) has accentuated the technological bias among the least qualified workers. Inequalities in income and wealth have been fostered, by the increase in financial savings in the wealthiest households and the increase in debt among the most financially constrained households, by the greater gap between the rate of return on financial capital and the rate of return on physical capital, a greater concentration of capital and a weakening of trade union power, and the hyper-financialization of economies. Interested readers can refer to the following recent papers in the abundant literature on the ramping inequalities in the US (Bozio et al., 2020; Komlos, 2019; Saez and Zucman, 2020).

Table 4 shows our estimates and the figures in Appendix D show some graphs of the natural interest rates, potential growth, GDP and output-gaps.

\section{United States}

We start with the results obtained for the United States. When inequalities are included among the explanatory variables, potential growth become more volatile (see, Figure 1 , blue curve). Omitting these variables thus leads to over- or underestimate potential growth. Specifically, during time of strong recessions, here during the 2000-2002 dot-com bubble bust and the 2008-2009 financial crisis, inequalities lead to more pronounced drops in potential growth than usually admitted with the standard LW model. Comparing the black and blue curves, we see that during the dot-com crisis the slowdown in potential growth might have been under-estimated by more than 1\%. The GR is likely to have led potential growth to a decrease of up to $-3 \%$. In 2015 and 2016, the US experienced what is sometimes referred to as an "invisible recession"with a sharp slowdown in business investment caused by the conjunction of several factors (run-up of the dollar, drop in international commodity prices, including oil, and slowing demand in the emerging countries). In Figure 1, we see that the negative effects of these events on potential growth might have been aggravated by the increasing inequalities, thereby leading to a trajectory of potential growth below the LW path estimated without them. 
The higher volatility of potential growth is transmitted to the natural interest rate as well (see Figure 2). This can be seen by comparing the blue and black curves. A striking -new- feature here is the existence of two regimes. We see one regime in which the natural rate of interest is positive, around the years corresponding to the GR, and a second regime with negative natural rates outside this period. One explanation is that, when inequality variables are taken into account, the predominant channels linking the crisis to the dynamics of the natural interest rate are neither linked to real variables (such as the rate of return on capital), nor to monetary variables (quantitative easing policy). Indeed, if this were the case, we would have observed a fall in the natural rate. Here, the main channel through which inequalities may have influenced the natural rate is debt reimbursement by the private sector. The crisis has led to a very high level of dis-saving by households and firms. If we assume that the natural rate reflects the balance between aggregate savings and investment, then massive deleveraging by the private sector, such as that observed after the financial crisis, has raised the natural interest rate. This phenomenon is more accentuated when inequalities are high.

Figure 3 shows that the financial crisis of 2008 resulted in a fall in the level of potential GDP that was larger than the usual estimates (without inequality variables) suggest. A comparison of output gaps in Figures $4 \mathrm{a}$ and $4 \mathrm{~b}$ shows that, by not taking inequalities into account, the depth of recessions (negative output gap) is often underestimated and the extent of expansionary phases (positive output gaps) are overestimated. For the year 2009 we see a zero-output gap, which can be explained by the fact that the crisis has not only caused a fall in aggregate demand but also, at the same time, it has led to a decline in potential GDP.

\section{Germany}

Let us compare these results with those obtained for Germany. In this country, inequalities rose sharply in the first half of the 2000s. The explanatory factors are multiple: the exportled growth model prompted a small increase in wages, wealth inequality augmented more than in any other euro area country, labour markets underwent a strong transformation with the adoption of the Hartz reforms between 2006 and 2011, and the positive effects of public redistribution policies 10 years after the German reunification halted. Figure 5 suggests that potential growth with inequalities was much lower than the standard estimate. In particular, the blue curve indicates that the falls in potential growth may have 
been underestimated during the 2009 financial crisis.

The two curves (with and without the inequalities) are, nonetheless, closer from 2013 onward. One explanation can be that several factors have contributed to erasing the effects of inequalities. There was a change in wage policies, which, in a context of sustained growth, has led real wages to grow faster than labour productivity. This mechanically produced an increase in the wage share out of total income and stimulated aggregate demand. The difference between the curves, before and after 2013, could therefore illustrate the positive effect on potential growth of the end of wage moderation. The closer curves may also illustrate the effects of the introduction of a minimum wage from 2015.

Figure 6 shows that the path of the natural rate, with inequality variables, resembles that of potential growth rate. In contrast to the United States, a significant fall in the rate can be observed corresponding to the years of the GR. Figure 7 shows that inequalities can also imply a drop in the level of potential GDP per-capita, thereby suggesting that the estimated output-gaps in Germany may have been very much overestimated compared to what they were.

Japan

Japan is an atypical case compared to the other two countries. Income and wealth inequalities are as high as in the other industrialized countries and the country has a large number of poor people (16\% of the population lives below the poverty line). Strangely, this has little effect on the estimates of potential GDP and output-gaps (see Figures 8, 9 and 10). Inequalities, however, affect potential growth and the natural interest rate. Inequality tends to undermine potential growth when the latter is positive (in Figure 8 , when $g^{*}$ is positive, the black curve is very often above the blue one). However, during strong recessions, the curves have the reverse positions, which suggests that households with the lowest incomes and wealth are not necessarily those who suffer the most from recessions.

As in the US case, the estimated natural interest rate with inequality variables is more volatile than the standard natural interest rate. The V-shaped curve suggest that both natural rates have been influenced by monetary policy. First, since the beginning of the QE policy in March 2001, the natural rate has remained negative most of the time. We see the large trough corresponding to the implementation of the CME (Comprehensive Monetary 
Easing) policy. Such a policy consisted in buying sovereign and risky corporate bonds from the private sector, and at the same time engaging into a forward guidance policy to anchor inflation expectations. Such a policy caused the natural rate to plunge due to the abundance of liquidity in the markets. It can be noticed that, although negative, the natural interest rate evolves along a positive trend since 2016, the year of the implementation of the QQE policy (Quantitative and Qualitative Easing) aiming at redressing the right-end of the yield curve to raise the level of long-term interest rates.

\section{Comparing the estimation with and without inequality variables}

Table 4 shows our estimates. The numbers in bold are the coefficients that are statistically significant at $5 \%$ level of significance. signif is the significance level. The columns labelled (1) correspond to estimates with inequality variables and those labelled (2) show estimates without inequality variables.

For the United States, we see that GDP persistence, usually captured by the LW model, disappears when inequality variables are introduced. The output gap variable is no longer significant in the AS equation. Wealth inequality and inequalities captured by income dispersion contribute to a decrease in potential GDP and thus to a wider output-gap (which is indicated by a positive coefficient of the Palma ratio and wealth variables). Moreover, when the number of low-wage earners rises, this has deflationary pressure. The coefficient of the output-gap in the AS curve becomes insignificant in the equation with the inequality variables, which can be explained as follows: inequality reduces the likelihood of a strong effect of an expansion on employment, thereby reducing the upward pressure on wages and hence on prices.

The estimates for Japan contrast with those obtained for the United States. The inequalities measured by the Palma ratio and those related to wealth favor the appearance of recessions (negative signs of the Palma ratio and Wealth coefficients). The aggregate supply curve is vertical (the coefficient of the output gap, which is very high, becomes significant when inequality variables are introduced into the AS equation). This is consistent with the observation of persistent disinflation - or even deflation - in Japan. Low wages contribute twice as much to disinflation there than in the US. Unlike the US, the introduction of inequality variables in the model has little effect on the estimated coefficients for Japan. 
For the German case, some results are identical to those of Japan. Specifically, inequalities linked to Wealth and Palma ratio are likely to increase the risk of recessions (we find negative and significant coefficients for these variables). On the other hand, the sign of the low paid workers variable is positive, which is a consequence of the German export-led growth model: wage compression has been an element of competitiveness of the German economy on world markets. Unlike the other two countries, we find a down-sloping aggregate supply curve. There are several explanations. The first is the existence of important economies of scale: as output rises, costs per unit decrease. Another explanation is that lower prices mean higher profits for the economy.

Concerning the variable "gender gap" it turns out to be significant in the three cases, although the sign is different: positive for the United States and Japan and negative for Germany. A potential explanation would be based on the models relating fertility to growth, with the following underlying mechanism. Assume that an economy's capital per-worker is more complementary to women' labor than to men's. An increase in the gender gap (in the case of our variable, a higher percentage of men relative to women participating in the labor market) reduces women's relative wages (as share of total wages). This lowers the opportunity cost of having children. An increase in fertility is thus accompanied by a lower growth rate (because lower women's labor supply means lower capital) and this exerts a negative impact on the natural interest rate. If instead capital and women' labor are substitutable, we have the opposite effect of an increase in the gender gap. If the explanation holds, then the positive sign for the US and Japan and the negative sign for Germany would capture the fact that, in Germany, capital per worker is more complementary to women compared to the other two countries.

In all regressions, the impact of the real interest rate gap on the output-gap seems to be very weak. All the estimated output-gaps display persistent dynamics.

\section{Implications for monetary policy rules}

\subsection{A simple analytical model}

We now investigate whether taking inequality into account in the calculation of the natural interest rate (which is a target for the short-term policy rate) and potential GDP changes 
the stance of monetary policy relative to a situation where these considerations are omitted. The idea that monetary policy has a role to play in combating inequalities is gaining renewed interest in the economic debate, after having been supplanted by an approach focused exclusively on controlling inflation and fighting unemployment though the issue is an old one. For example, in the United States, the Community Reinvestment Act allows the US Federal Reserve to adopt measures facilitating access to credit for the lowest income households. The economic literature has highlighted different transmission channels. The first effects occur through "inflation tax" on nominal cash holdings of the lowest-income households, while at the same time rising prices increase the value of real assets held by higher-income households. Indeed, the wealth of the former is more often held in monetary form (cash deposits), whereas the latter more easily own real assets (for example, housing or businesses). Other redistributive effects play through nominal interest rate changes. Interest rate cuts have two effects. On the one hand, they lead to a redistribution from savers or lenders to borrowers (with possible intergenerational transfers insofar as savers are old and borrowers are young). On the other hand, they increase wealth inequality, as the reduction in interest rates pushes up the prices of financial assets (thus increasing the wealth of the richest agents). Finally, monetary policy, through its effect on the business cycle, can change the distribution of income as a result of employment effects. Lower interest rates stimulate growth and employment. The redistributive effects depend on the position of workers in the wage and income distribution, and on the sensitivity of the types of jobs - skilled and unskilled - to variations in aggregate demand.

To build intuition about the impact of inequality on the stance of monetary policy, it is interesting to investigate whether the achievement of some targets on inequality variables requires putting more weight on output and inflation gaps than in a standard framework. Before looking at some empirical results, we build some intuition by considering a basic conceptual framework.

We use a simple setup where a central bank bases its policy on an optimal interest rate rule. Suppose that it has the following quadratic loss function in which, in addition to the usual inflation-gap and output-gap, it is assigned the mandate of stabilizing inequalities. Define $w_{t}^{*}$ the desired level of one the inequality variables defined in Equation 2 and consider the following loss function:

$$
\text { Loss }=\frac{-1}{2}\left[\widetilde{y}_{t}^{2}+\theta \widetilde{\pi}_{t}^{2}+\kappa\left(r_{t}-r_{t-1}\right)^{2}+\omega\left(\widetilde{w_{t}}\right)^{2}\right]
$$


where $\widetilde{y_{t}}=y_{t}-y_{t}^{*}, \widetilde{\pi_{t}}=\pi_{t}-\pi_{t}^{*}, \widetilde{w_{t}}=w_{t}-w_{t}^{*}$.

The introduction of inequality variables into the loss function of a central bank can be motivated by the need to combat the risks of financial instability. Indeed, one of the drivers of financial crises over the last decade in the industrialized countries has been the explosion of private debt. Income inequalities have played an important role in the dynamics of household credit. Inequalities increased sharply in a context of impoverishment of countries' middle class. A preventive fight against financial crises therefore involves redistributive policies aimed at reducing income inequalities. An alternative interpretation is that, although the central bank is not directly responsible for policies to fight inequalities (this is rather the responsibility of governments), it takes these policies into account when setting its policy rate.

It is equivalent to choose the real interest rate $r_{t}$ or the nominal interest rate $i_{t}$ as the policy instrument since by definition $i_{t}=r_{t}+\pi_{t} .\left(r_{t}-r_{t-1}\right)$ accounts for interest rate smoothing. To describe the economy consider simpler forms of Equations (1) and (2):

$$
\begin{gathered}
\widetilde{y_{t}}=-\mu_{r}\left(r_{t}-r_{t}^{*}\right)+a_{z} z_{t}+\sigma_{\widetilde{y}} \epsilon_{t}^{\widetilde{y}}, \quad \epsilon_{t}^{\widetilde{y}} \approx N(0,1) . \\
\pi_{t}=b_{\pi} \pi_{t-1}+b_{y} \widetilde{y}_{t}+b_{w} w_{t}+\sigma_{\pi} \epsilon^{\pi}, \quad \epsilon^{\pi} \approx N(0,1) .
\end{gathered}
$$

where $w_{t}$ and $z_{t}$ are one of the inequality variables that impact inflation and the output. We omit the lags on the endogenous and exogenous variables to keep the presentation simple. This does not change our arguments.

Our question is whether it is feasible to reach simultaneously $\widetilde{y_{t}}=\widetilde{\pi}_{t}=\widetilde{w_{t}}=0$. Denoting $\lambda_{1}$ and $\lambda_{2}$ the Lagrangian multipliers of the single period minimization program subject to the constraints 10 and 11, we obtain the following first-order conditions:

$$
\begin{gathered}
\frac{\partial L}{\partial \pi_{t}}=0 \rightarrow \theta \widetilde{\pi}_{t}=\lambda_{1}, \\
\frac{\partial L}{\partial \widetilde{y_{t}}}=0 \rightarrow \frac{\widetilde{y_{t}}}{b_{y}}=\frac{\lambda_{2}}{b_{y}}-\lambda_{1}, \\
\frac{\partial L}{\partial r_{t}}=0 \rightarrow \kappa\left(r_{t}-r_{t-1}\right)=\lambda_{2} \mu_{r}, \\
\frac{\partial L}{\partial w_{t}}=0 \rightarrow \frac{-\omega \widetilde{w_{t}}}{b_{w}}=\lambda_{1} .
\end{gathered}
$$


where $\lambda_{1}, \lambda_{2}$ measure the rate of change of the loss function as constraints (11) and (10) are relaxed. We look at the effect of each of the constraints on the inflation-output trade-off.

Setting $\lambda_{2}=0$, we obtain the following equalities

$$
r_{r}=r_{t-1}, \quad \widetilde{\pi}_{t}=\frac{-1}{b_{y} \theta} \widetilde{y}_{t}, \quad \widetilde{\pi}_{t}=\frac{-\omega}{b_{w} \theta} \widetilde{w_{t}} .
$$

Is inequality reduction compatible with the trade-off between inflation and output? Let us recall from our estimation results the following sign of the coefficients of the variables $W_{t}$ (Table 2 ). $+, 0,-$ indicate respectively a positive, non-significant or negative value of the variable on inflation.

Table 2: Impact of inequality variables on inflation

\begin{tabular}{cccc}
\hline & USA & Japan & Germany \\
\hline Gender-gap & + & + & - \\
\hline Labor income & 0 & 0 & 0 \\
& & & \\
\hline Low pay workers & - & - & + \\
\hline
\end{tabular}

Suppose that inflation rate is below target $\left(\widetilde{\pi}_{t}<0\right)$. The central bank must cut the interest rate to expand aggregate demand (according to the second equality in (16)). But it must also ensure that inequalities are moving in the right direction to allow a decrease in inflation. The third equality in (16) says that for inflation to increase $\widetilde{w_{t}}$ should decrease and so $w_{t}$ should diminish below its target.

Consider the example of low pay workers. A decrease in the proportion of workers with low wages is inflationary in the United States and Japan. Therefore, in these countries, a policy of wage increases when inflation is too "low" (below its target) is enough to raise inflation and this development is compatible with the central bank's policy of stimulating demand (when the inflation rate is below the target the central bank lowers its policy rate). In Germany, on the other hand, the sign of the coefficient of low pay workers in the inflation equation is positive. This implies that a decrease in the number of low-paid workers has deflationary effects, which prevents inflation from moving in the "right" direction to close the inflation gap. Only an increase in the number of low-paid workers would be compatible with the trade-off between inflation and unemployment. The monetary authorities thus face a dilemma of increasing inflation at the cost of allowing inequalities to rise. If we 
would consider the gender-gap, such a dilemma would be observed in the United States and Japan.

This type of dilemma is explained by the fact that the introduction of inequalities in the loss function "breaks" the divine coincidence in Blanchard's sense. If $\omega=0$ (no inequalities are taken into account), from the first-order conditions, we immediately have that at the optimum, the interest rate is constant, and the inflation and output gaps are zero. The divine coincidence describes the unique link between inflation and output: setting the inflation rate at its target is sufficient to close the output gap. In the case where $\omega \neq 0$, we add a constraint and the relation is no longer unique.

Now, we consider the case where, instead of $w_{t}$, one of the variables in the vector $Z_{t}$ enters the loss function. Our interest focuses on the gap $\widetilde{z_{t}}$. Combining the first-order conditions and setting $\lambda_{1}=0$, we obtain the following conditions:

$$
\widetilde{\pi}_{t}=0, \quad \widetilde{y_{t}}=\frac{\kappa}{\mu_{r}}\left(r_{t}-r_{t-1}\right), \quad \widetilde{y_{t}}=\frac{-\omega}{a_{z}}\left(\widetilde{z_{t}}\right) .
$$

Unlike before, where at the optimum the interest rate was fixed (we had $r_{t}=r_{t-1}$ ), the interest rate has now a variance that is not zero. The central bank changes its policy rate to keep inflation at its target, and any difference in interest rates observed between two periods allows maintaining an output gap compatible with a certain level of inequality.

Assume that $\mu_{r}<0, \omega>0$, and $\kappa>0$. The sign of $a_{z}$ measures the impact of inequalities on the output-gap. Based on our estimations, the sign of the coefficients in the (AD) curve are shown in Table 3.

Table 3: Impact of inequality variables on output-gap

\begin{tabular}{cccc}
\hline & USA & Japan & Germany \\
\hline Gini index & - & + & 0 \\
\hline Palma ratio & + & - & 0 \\
\hline Wealth inequality & + & - & - \\
\hline
\end{tabular}

Suppose that $a_{r}$ is positive. When output falls below its potential, the interest rate must fall to stimulate demand. This must be compatible with a reduction in inequality according to the second and third equality of (17). Conversely, if $a_{r}$ is negative, the increase in output resulting from the rate cut is only compatible with an increase in inequalities above their target. 
Considering the example where the loss function includes the variable $w$ as an inequality indicator, the first-order conditions of the constrained minimization program yield two reaction functions (two interest rate rules):

$$
r_{t}=r_{t-1}+\left(\frac{\mu_{r}}{\kappa}\right) \widetilde{y}_{t}+\left(\frac{\mu_{r} b_{y} \theta}{\kappa}\right) \widetilde{\pi}_{t}
$$

and

$$
r_{t}=r_{t-1}+\left(\frac{\mu_{r}}{\kappa}\right) \widetilde{y_{t}}-\left(\frac{\mu_{r} b_{y} \omega}{\kappa b_{w}}\right) \widetilde{w_{t}}
$$

The two rules coincide if there are some economic mechanisms that guarantee the existence of a particular relationship between the inflation gap and the inequality gap:

$$
\widetilde{\pi}_{t}=\left(\frac{-\omega}{\theta b_{w}}\right) \widetilde{w_{t}}
$$

In this case, it is equivalent to targeting inflation or inequalities, and the interest rate rule is described by Equation (18). But if the constraint described by Equation (20) is not satisfied, then the central bank must take its decision based on a combination of the two rules (18) and (19). In this case, the weight assigned to the output target is identical to that of a rule without the inequality variables, but the weight assigned to the inflation target is lower. Indeed, an example of a composite rule is a linear combination leading to

$$
\xi r_{t} \text { (given by 18) }+(1-\xi) r_{t} \text { (given by 19), } \xi \in(0,1)
$$

i.e.

$$
r_{t}=r_{t-1}+\left(\frac{\mu_{r}}{\kappa}\right) \widetilde{y_{t}}+\xi\left(\frac{\mu_{r} b_{y} \theta}{\kappa}\right) \widetilde{\pi}_{t}+(1-\xi)\left(\frac{-\mu_{r} b_{y} \omega}{\kappa b_{w}}\right) \widetilde{w_{t}}
$$

The same type of arguments applies if instead of $w_{t}$, one of the inequality variables $z_{t}$ that influence aggregate demand is considered in the loss function.

The first order conditions lead to the following two equations:

$$
r_{t}=r_{t-1}+\left(\frac{\mu_{r}}{\kappa}\right) \widetilde{y}_{t}+\left(\frac{\mu_{r} b_{y} \theta}{\kappa}\right) \widetilde{\pi}_{t}
$$

and

$$
r_{t}=r_{t-1}-\left(\frac{\omega \mu_{r}}{\kappa a_{z}}\right) \widetilde{z_{t}}+\left(\frac{\mu_{r} b_{y} \theta}{\kappa}\right) \widetilde{\pi}_{t} .
$$


The two rules coincide if

$$
\widetilde{y_{t}}=\left(-\frac{\omega}{a_{z}}\right) \widetilde{z_{t}}
$$

If the constraint (25) is satisfied, it is equivalent to stabilize output and inequalities. (18) and (23) are similar. If not, then the central bank must adopt a mixture of both rules:

$$
r_{t}=r_{t-1}+\left(\frac{\mu_{r} b_{y} \theta}{\kappa}\right) \widetilde{\pi}_{t}+\xi\left(\frac{\mu_{r}}{\kappa}\right) \widetilde{y_{t}}+(1-\widetilde{\xi})\left(\frac{-\omega \mu_{r}}{\kappa a_{z}}\right) \widetilde{z_{t}}
$$

In this case, the coefficient of the output gap changes compared to a situation without inequalities in the loss function. If we introduce the two types of inequality into the loss function, both coefficients of the output gap and the inflation gap would change.

Our conclusion is as follows. When inequality variables are introduced into the central bank's objective function, this has two possible effects for the interest rate rules. The first is a case of divine coincidence: by simply targeting inflation and the output gap, the central bank also stabilizes inequalities. But this presupposes the verification of constraints linking them. The second case is when the central bank has an instrument to achieve three different objectives. This changes the sensitivity of the variation in interest rates to the output gap and the inflation gap.

\subsection{Econometric evidence}

To "test" the conclusions of the previous section on real data, we estimate three reaction functions supposed to describe the monetary policy of the US, Germany and Japan.

The first equation is the dynamic form of a standard interest rate rule where the gap between the short-term interest rate and its target depends on the inflation growth rate gaps. The interest rate target corresponds to the natural interest rate estimated in the previous sections (without inequality variables in AS and AD equations) and the growth target corresponds to the potential growth rate estimated from the same model without the inequality variables:

$$
[1-\beta(L)]\left(r_{t}^{n}-r_{t}^{*}-\pi_{t}^{*}\right)=c+\alpha_{g}(L)\left(g_{t-1}-g_{t-1}^{*}\right)+\alpha_{\pi}(L)\left(\pi_{t-1}-\pi_{t-1}^{*}\right)+\epsilon_{t}^{1},
$$

where

$r_{t}^{n}:$ nominal short-term rate $=$ real shadow rate+core inflation; 
$r_{t}^{*}+\pi_{t}^{*}$ : nominal natural rate of interest;

$r_{t}^{*}$ : natural rate of interest estimated in the last section; $\pi_{t}^{*}$ : inflation target $=2 \%$;

$g_{t}-g_{t}^{*}$ : growth gap $=$ observed growth minus potential growth estimated in the last section;

$\pi_{t}$ : inflation rate;

$\epsilon_{t}$ : residual term;

and $\alpha(L)$ and $\beta(L)$ are lag polynomials.

The second equation is similar to Equation (27) but $r_{t}^{*}$ and $g_{t}^{*}$ are the natural interest rate and potential growth estimated in the last section when inequality variables are considered in the AS and AD equations:

$$
[1-\beta(L)]\left(r_{t}^{n}-r_{t, \text { ineq }}^{*}-\pi_{t}^{*}\right)=c+\alpha_{g}(L)\left(g_{t-1}-g_{t-1, \text { ineq }}^{*}\right)+\alpha_{\pi}(L)\left(\pi_{t-1}-\pi_{t-1}^{*}\right)+\epsilon_{t}^{2}
$$

In the third regression, we add the inequality variables that are in AD and AS as explanatory variables along with the inflation and growth gaps:

$$
\begin{array}{r}
{[1-\beta(L)]\left(r_{t}^{n}-r_{t, \text { ineq }}^{*}-\pi_{t}^{*}\right)=c+\alpha_{g}(L)\left(g_{t-1}-g_{t-1, \text { ineq }}^{*}\right)+\alpha_{\pi}(L)\left(\pi_{t-1}-\pi_{t-1}^{*}\right)+} \\
\boldsymbol{\Theta}(\boldsymbol{L}) \boldsymbol{W}_{\boldsymbol{t}}+\boldsymbol{\Omega}(\boldsymbol{L}) \boldsymbol{Z} \boldsymbol{t}_{\boldsymbol{t}}+\boldsymbol{\epsilon}_{t}^{3},
\end{array}
$$

The symbols in bold indicate vectors. The components of $\Theta(L)$ and $\Omega(L)$ are lag polynomials.

Equations (27) to (29) are estimated using ARDL estimator (autoregressive distributed lag) with a maximum of 2 lags.

Tables 5 to 10 present the estimation results for the three countries. We distinguish two periods, before and after 2008, taking into account the changes in monetary policy regime. We investigate the reaction function of the central banks' interest rate had they followed a policy rate setting rule involving stabilization objectives of the inequality variables at target values.

When inequality variables are considered into the interest rate equation, at least one has 
a significant coefficient. This is evidence of the absence of "divine coincidence". When central banks calculate their natural interest rate target and potential growth $\left(r^{*}\right.$ and $\left.g^{*}\right)$ from a model that takes into account the macroeconomic consequences of inequality, targeting and stabilizing inflation and/or the output gap alone is not enough to stabilize the inequality variables around their target. When inequality variables are not included in the regressions (where $r^{*}$ and $g^{*}$ are calculated taking into account the $\mathrm{Z}$ and $\mathrm{W}$ variables), the parameters change, which suggests the presence of omission bias.

What would have been the reaction function of central banks if they had followed a policy rate setting rule that took into account the stabilization objectives of inequality variables at target values? To answer we compute for each sub-period the first and the third regressions.

In the United States, before 2008, the reaction function without the inequality variables shows a counter cyclical reaction to inflation and growth gaps. Indeed, the significant coefficients are positive (i.e. 2.17 for inflation and $0.9=0.26-0.16$ for growth). Taking into account inequality objectives would have led the Fed to change the stance of monetary policy, by conducting a pro-cyclical policy with regards to growth (the coefficient of the growth gap turns to negative, i.e. -0.24) and by having a less stringent counter-cyclical policy with respect to inflation (the coefficient decreases to $0.16=4.02-3.86$ ).

The post-2008 period corresponds to the implementation of unconventional monetary policies. The reaction function without inequality variables shows that the monetary policy stance does not depend on the growth gap and is positively correlated with the inflation gap (the coefficient is positive, i.e. $0.36=1.63-1.27$ ). The period of significant interest rate decline coincided with a strong period of disinflation. Taking account of inequality variables would have made monetary policy stance weakly pro-cyclical with respect to growth (the coefficient equals $-0.06=-0.27+0.19$ ) and weakly counter-cyclical with respect to inflation (the coefficient is $0.75=1.55+1.61-2.41$ ).

In the case of Japan, before 2008, monetary policy, without inequality variables, was strongly counter-cyclical in a context of disinflation, when the Bank of Japan started (before the other central banks) unconventional policies in the hope of bringing up prices. The addition of inequality objectives would have led to a strengthening of this policy (with a positive coefficient for the inflation gap rising from 2.54 to 4.79 ) and a pro-cyclical 
policy favoring growth (negative coefficient equal to -0.18). For the post-2008 period, the monetary policy stance depends on the growth rate gap in a pro-cyclical manner, when inequality variables are not included in the reaction function. Introducing these variables in the equation changes the sign of the coefficients of inflation and growth gaps: they respectively turn from zero -insignificant - to a negative value for the former and from a negative (-0.64) to a positive value (i.e $-2.03=1.02-3.05)$ for the latter. Thus, taking inequality into account would have led to the promotion of growth above potential growth - and thus to the adoption of a policy leading to lower interest rates - while controlling inflationary pressures in order to avoid its potential negative effects on the increase in inequality.

The results for Germany in the pre-2008 period are similar to those obtained for the United States. Indeed, without inequalities, the interest rate policy is counter-cyclical, both in terms of inflation control and growth (the coefficients are significantly positive). Then, incorporating inequalities would have made it pro-cyclical, since the coefficients of both gaps become significantly negative. After 2008, the highly expansive unconventional monetary policy is de facto pro-cyclical and the effect on the stance of monetary policy appears on the coefficient of inflation, which is negative in the first regression. The policy would have been pro-cyclical if inequality targets had been added to the policy rule.

The results obtained for the three countries suggest that taking inequality into account in central banks' monetary policy would have changed the stance of monetary policy. According to the standard economic analysis, a surge in inflation or an economic recovery above potential growth should push the policy rate up (because the positive sign of the coefficients is a necessary condition for the stability of the macroeconomic equilibrium in the AS-AD model). We show that taking inequality into account may lead to a change in this orientation with, on the contrary, a policy that encourages inflationary recoveries (this may help, for example, to reduce the real debt burden for the poorest households) and to stimulate growth recoveries (given the beneficial effects on income, employment, etc).

\section{Conclusions}

In this paper, we have attempted to provide new estimates of the natural interest rates and potential growth taking into account the role of inequality variables in both aggregate demand and aggregate supply. Our results suggest that the omission of inequality issues 
may generate biases in economic interpretation, since we have seen that such variables can modify drastically the paths of interest rates and growth at their neutral levels. Interestingly, for the United States, our findings are in accordance with the view that natural rates are driven by the financial cycle, which could explain a negative correlation between potential growth and neutral interest rates in both times of recessions and expansions. Therefore, growing inequality may constitute a drawback for the recovery of the economy. Another interesting finding concerns Japan, where inequality does not seem to affect that much the estimates of output-gaps and potential GDP.

Since the natural rate of interest is usually presented as a possible target for the policy rate of central banks, we studied the effects of our estimates for the reaction functions of the monetary authorities, assuming that they are derived from loss functions that include the objectives of monetary policy. We find two results to be important. First, that the presence of inequality variables calls into question the idea that all possible policy objectives are "subordinated" to the inflation objective. This was true in an economy where only the inflation-growth trade-off is considered. In this case, stabilizing inflation is enough to stabilize growth. The introduction of inequality targets breaks this automatic link. This forces central banks to make "concessions" on their usual objectives. Thus, a second important result is that the monetary policy aiming at stabilizing inflation and growth can become pro-cyclical. When inequality is high, rather than curbing a recovery for fear that it will eventually lead to inflationary pressures, it may be preferable to accompany it (by cutting rates rather than raising them). The exercise in the previous section can be applied to a situation where the central banker continues to target inflation and employment, but incorporates fiscal policy objectives into its loss function. In this case, the loss function we introduced could be applied to study the effects of a policy mix around inequality. Making concessions on inflation and growth is a way for the monetary authorities to accompany the fiscal authorities in the fight against inequality. Another possible interpretation is that central banks can set their natural interest rate and potential growth targets with a view to directing the financing of the economy towards activities that contribute to reducing inequality.

Despite the interesting results, our work deserves some caution, as our estimation of the natural rate contains the usual caveats of the LW models. A pitfall is the sensitivity of the estimates to the selection of the starting values for the parameters, which sometimes makes 
the estimates difficult to interpret. 


\section{References}

Acemoglu, D., Johnson, S., and Robinson, J. (2004). Institutions as the Fundamental Cause of Long-Run Growth. NBER Working Paper Series, 284.

Aiyagari, S. R. (1994). Uninsured Idiosyncratic Risk and Aggregate Saving. The Quarterly Journal of Economics, 109(3):659-684.

Alesina, A. and Perotti, R. (1996). Income distribution, political instability, and investment. European Economic Review, 40(I 996):1203-1228.

Amaral, P. (2017). Monetary Policy and Inequality. Economic Commentary. Federal Reserve Bank of Cleveland.

Baldwin, R. (2019). The globotics upheavel: globalization, robotics and the future of work, volume 98. Oxford University Press, New York, NY, USA.

Baldwin, R. (2020). The COVID-19 upheaval scenario : Inequality and pandemic make an explosive mix. VOX CEPR Policy Portal, pages 1-5.

Baldwin, R. and Weder di Mauro, B. (2020). Economics in the Time of COVID-19. CEPR, London.

Bartscher, A. K., Kuhn, M., and Schularick, M. (2020). The college wealth divide: Education and inequality in America, 1956-2016. Federal Reserve Bank of St. Louis Review, 102(1):19-49.

Benigno, G. and Fornaro, L. (2018). Stagnation traps. Review of Economic Studies, 85(3):1425-1470.

Bernanke, B. B. I. (2015). Why are interest rates so low , part 2 : Secular stagnation.

Bhaumik, S. (2011). Productivity and the Economic Cycle. BIS Economics Paper, 12.

Blanchard, O. J. (1985). Debt, Deficits, and Finite Horizons. Journal of Political Economy, 93(2):223-247.

Bozio, A., Garbinti, B., Goupille-Lebret, J., Guillot, M., and Piketty, T. (2020). Predistribution vs. Redistribution: Evidence from France and the U.S. CEPR Discussion Paper Series, 15415.

Brynjolfsson, E. and McAfee, A. (2014). Second Machine Age: Work, Progress, and Prosperity in a Time of Brilliant Technologies. Norton \& Company.

Calvert Jump, R. (2018). IInequality and Aggregate Demand in the IS-LM and IS-MP Models. Bulletin of Economic Research, 70(3):269-276.

Cuberes, D. and Teignier, M. (2012). Gender Gaps in the Labor Market and Aggregate Productivity. Sheffield Economic Research Paper Series, 2012017.

Cynthia Fan Dora Xia, J. W. (2016). Measuring the Macroeconomic Impact of Monetary Policy at the Zero Lower Bound. Journal of Money, Credit, and Banking, 48(2-3):253-291.

Eggertsson, G. B., Mehrotra, N. R., and Robbins, J. A. (2019). A model of secular stagnation: Theory and quantitative evaluation. American Economic Journal: Macroeconomics, 11(1):1-48. 
Engen, E. M. and Gruber, J. (2001). Unemployment insurance and precautionary saving. Journal of Monetary Economics, 47(3):545-579.

Faggio, G., Salvanes, K., and Reenen, J. V. (2007). The Evolution of Inequality in Productivity and Wages: Panel Data Evidence. NBER Working Paper Series, 13351.

Fornaro, L. and Wolf, M. (2020). COVID-19 Coronavirus and Macroeconomic Policy. CEPR Discussion Paper Series, 20(14529).

Furman, J. and Orszag, P. (2018). Slower Productivity and Higher Inequality: Are They Related? Peterson Institute for International Economics WP, 4.

García-Penalosa, C. (2007). Growth and income distribution in an integrated Europe : Does EMU make a difference? Conference Paper. Forth Annual DG ECFIN Research Conference, (October):1-39.

Gertler, M. (1999). Government debt and social security in a life-cycle economy. Carnegie-Rochester Conference Series on Public Policy, 50:61-110.

Gordon, R. J. (2012). Is U.S. economic growth over? faltering innovation confronts the six headwinds. NBER Working Paper Series, 12.

Gordon, R. J. (2016). The Rise and Fall of American Growth: The U.S. Standard of Living since the Civil War. Princeton University Press, Princeton, New Jersey.

Hansen, A. H. (1939). Economic Progress and Declining Population Growth. American Economic Review, 98(5):iv.

Holston, K., Laubach, T., and Williams, J. C. (2017). Measuring the natural rate of interest: International trends and determinants. Journal of International Economics, 108:S59-S75.

Kaplan, G., Violante, G. L., and Weidner, J. (2014). The wealthy hand-to-mouth. Brookings Papers on Economic Activity, Spring 201:139-153.

Komlos, J. (2019). Growth of Income and Welfare in the U.S., 1979-2011. Journal of Income Distribution, 28(1):1-19.

Krippner, L. (2015). A comment on Wu and Xia (2015), and the case for two-factor Shadow Short Rates. Australian National University CAMA Working Paper, 48.

Krugman, P. (2014). Currency Regimes, Capital Flows, and Crises. IMF Economic Review, 62(4):470-493.

Laubach, T. and Williams, J. C. (2003). Measuring the Natural Rate of Interest. The Review of Economics and Statistics, 85(November):1063-1070.

OECD (2018). Decoupling of Wages from Productivity: What Implications for Public Policies? In OECD Economic Outlook, chapter 2, pages 51-65. OECD, Paris.

Oh, H. and Reis, R. (2012). Targeted transfers and the fiscal response to the great recession. Journal of Monetary Economics, 59(SUPPL.):S50-S64. 
Rachel, L. and Smith, T. D. (2015). Secular drivers of the global real interest rate. Bank of England Staff Working Paper, (571).

Rodrik, D. (1999). Where did all the Growth Go? External shocks, social conflict, and growth collapses. Journal of Economic Growth, 4(4):385-412.

Rogoff, K. (2015). Debt Supercycle, Not Secular Stagnation. VOX CEPR Policy Portal, pages 1-5.

Saez, E. and Zucman, G. (2020). The rise of income and wealth inequality in America: Evidence from distributional macroeconomic accounts. Journal of Economic Perspectives, 34(4):3-26.

Stiglitz, J. E. (2012). The Price of Inequality: How Today's Divided Society Engangers Our Future. W. W. Norton, New York.

Summers, L. (2013). Why Stagnation Might Prove to Be the New Normal.

Taylor, J. B. (2016). Slow economic growth as a phase in a policy performance cycle. Journal of Policy Modeling, 38(4):649-655.

Wu, J. C. and Zhang, J. (2019). A shadow rate New Keynesian model. Journal of Economic Dynamics and Control, 107. 


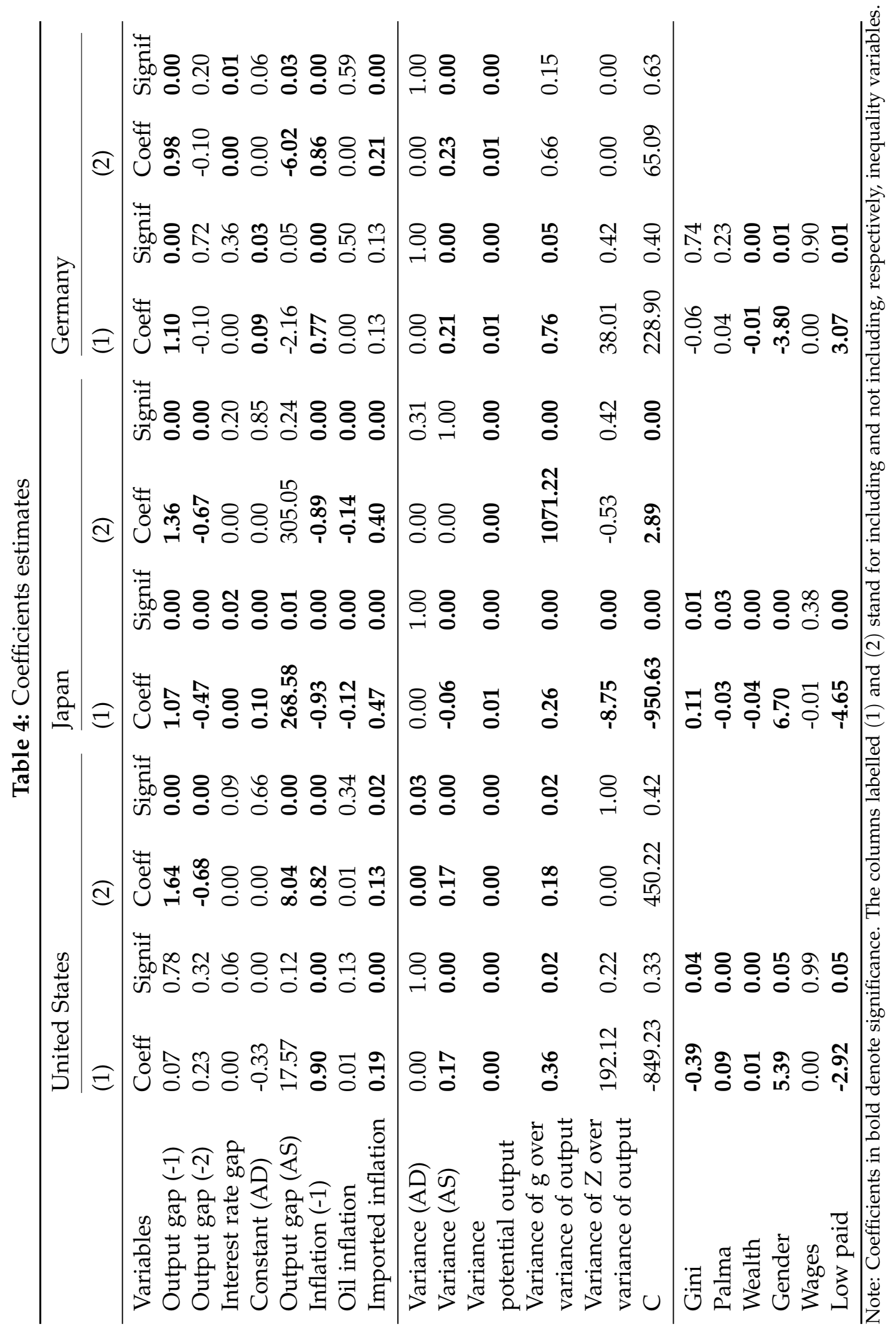


Table 5: Monetary policy rule : USA - 2000-2008

\begin{tabular}{|c|c|c|c|c|c|c|}
\hline \multirow{2}{*}{$\begin{array}{l}\text { USA 2001-2008 } \\
\text { Gap variables }\end{array}$} & \multirow{2}{*}{$\begin{array}{l}\mathrm{R}^{*} \text { and } \\
\text { without } \\
\text { equality } \\
\text { Coefs. }\end{array}$} & \multirow{2}{*}{$\begin{array}{c}\mathrm{y}^{*} \\
\text { in- } \\
\text { P-value }\end{array}$} & \multicolumn{2}{|c|}{$\begin{array}{l}\mathrm{R}^{*} \text { and } \mathrm{y}^{*}+\text { in- } \\
\text { equality }\end{array}$} & \multicolumn{2}{|c|}{$\begin{array}{l}\mathrm{R}^{*} \text { and } \mathrm{y}^{*}+\text { in- } \\
\text { equality }+ \text { exoge- } \\
\text { nous variables }\end{array}$} \\
\hline & & & Coefs. & P-value & Coefs. & P-value \\
\hline Interest rate(-1) & $1.03^{* * *}$ & 0.0002 & $1.41^{* * *}$ & 0.0 & 0.83 & 0.006 \\
\hline Interest rate(-2) & -0.35 & 0.12 & -0.44 & 0.14 & -0.36 & 0.13 \\
\hline Growth & $-0.16^{*}$ & 0.08 & -0.12 & 0.43 & $-0.24^{* *}$ & 0.02 \\
\hline Growth(-1) & $0.25^{* *}$ & 0.04 & - & - & -0.12 & 0.35 \\
\hline Growth(-2) & - & - & - & - & - & - \\
\hline Inflation & -1.04 & 0.27 & $-2.13^{*}$ & 0.07 & $-3.86^{* * *}$ & 0.003 \\
\hline Inflation(-1) & $2.17^{* *}$ & 0.04 & $1.82^{*}$ & 0.07 & $4.02^{* *}$ & 0.02 \\
\hline Inflation(-2) & - & - & - & - & -1.01 & 0.49 \\
\hline Intercept & $-0.93^{* *}$ & 0.04 & -0.14 & 0.59 & -37.51 & 0.92 \\
\hline Ineq. variables & Coefs. & $\mathrm{P}$-value & Coefs. & P-value & Coefs. & P-value \\
\hline Gini & - & - & - & - & -0.84 & 0.43 \\
\hline Gini(-1) & - & - & - & - & 2.03 & 0.22 \\
\hline Gini(-2) & - & - & - & - & -1.00 & 0.29 \\
\hline Palma & - & - & - & - & $1.0^{* * *}$ & 0.02 \\
\hline Palma(-1) & - & - & - & - & $-0.9^{*}$ & 0.06 \\
\hline Palma(-2) & - & - & - & - & 0.53 & 0.20 \\
\hline Wealth & - & - & - & - & $-0.22^{*}$ & 0.06 \\
\hline Wealth(-1) & - & - & - & - & - & - \\
\hline Wealth(-2) & - & - & - & - & - & - \\
\hline Gender & - & - & - & - & $4.13^{* *}$ & 0.05 \\
\hline Gender(-1) & - & - & - & - & -2.61 & 0.27 \\
\hline Gender(-2) & - & - & - & - & 1.37 & 0.46 \\
\hline Income & - & - & - & - & -0.001 & 0.72 \\
\hline Income(-1) & - & - & - & - & -0.002 & 0.38 \\
\hline Income(-2) & - & - & - & - & $0.01^{* * *}$ & 0.0038 \\
\hline Low paid & - & - & - & - & $199.02^{* *}$ & 0.05 \\
\hline Low paid(-1) & - & - & - & - & -87.67 & 0.28 \\
\hline Low paid(-2) & - & - & - & - & - & - \\
\hline$R^{2}$ & 0.81 & - & 0.87 & - & 0.99 & - \\
\hline $\mathrm{F}$ bound test & $1.96 *$ & - & $0.43^{*}$ & - & $8.6^{*}$ & - \\
\hline
\end{tabular}


Table 6: Monetary policy rule : USA - 2009-2019

\begin{tabular}{|c|c|c|c|c|c|c|}
\hline \multirow{2}{*}{$\begin{array}{l}\text { USA 2009-2019 } \\
\text { Gap variables }\end{array}$} & \multirow{2}{*}{$\begin{array}{l}\mathrm{R}^{*} \quad \text { and } \\
\text { without } \\
\text { equality } \\
\text { Coefs. }\end{array}$} & \multirow{2}{*}{$\begin{array}{c}\begin{array}{c}\mathrm{y}^{*} \\
\text { in- }\end{array} \\
\text { P-value }\end{array}$} & \multicolumn{2}{|c|}{$\begin{array}{l}\mathrm{R}^{*} \text { and } \mathrm{y}^{*}+\text { in- } \\
\text { equality }\end{array}$} & \multicolumn{2}{|c|}{$\begin{array}{l}\mathrm{R}^{*} \text { and } \mathrm{y}^{*}+\text { in- } \\
\text { equality }+ \text { exoge- } \\
\text { nous variables }\end{array}$} \\
\hline & & & Coefs. & $\mathrm{P}$-value & Coefs. & $P$-value \\
\hline Interest rate(-1) & $1.13^{* * *}$ & 0.0 & $1.19^{* * *}$ & 0.0 & $0.63^{* * *}$ & 0.0 \\
\hline Interest rate(-2) & $-0.27^{* *}$ & 0.0 & $-0.24^{*}$ & 0.08 & - & - \\
\hline Growth & 0.07 & 0.40 & $0.23^{* *}$ & 0.03 & $0.19^{* *}$ & 0.01 \\
\hline Growth(-1) & & & -0.13 & 0.12 & -0.09 & 0.27 \\
\hline Growth(-2) & & & & & $-0.27^{* * *}$ & 0.0001 \\
\hline Inflation & $-1.27^{* *}$ & 0.05 & $-1.45^{*}$ & 0.06 & $-2.41^{* * *}$ & 0.002 \\
\hline Inflation(-1) & $1.63^{* *}$ & 0.02 & $1.83^{* *}$ & 0.01 & $1.61^{*}$ & 0.08 \\
\hline Inflation(-2) & & & & & $1.55^{* *}$ & 0.02 \\
\hline Intercept & $-0.60^{* *}$ & 0.05 & 0.01 & 0.95 & $-164.01^{* *}$ & 0.03 \\
\hline Ineq. variables & Coefs. & P-value & Coefs. & P-value & Coefs. & P-value \\
\hline Gini & - & - & - & - & $8.40^{* * *}$ & 0.0 \\
\hline Gini(-1) & - & - & - & - & $-4.11^{* * *}$ & 0.0018 \\
\hline Gini(-2) & - & - & - & - & - & \\
\hline Palma & - & - & - & - & $-0.43^{* *}$ & 0.02 \\
\hline Palma(-1) & - & - & - & - & - & - \\
\hline Palma(-2) & - & - & - & - & - & - \\
\hline Wealth & - & - & - & - & $0.01^{*}$ & 0.06 \\
\hline Wealth(-1) & - & - & - & - & - & - \\
\hline Wealth(-2) & - & - & - & - & - & - \\
\hline Gender & - & - & - & - & $2.22^{* * *}$ & 0.0004 \\
\hline Gender(-1) & - & - & - & - & $-1.66^{* * *}$ & 0.002 \\
\hline Gender(-2) & - & - & - & - & - & - \\
\hline Income & - & - & - & - & $0.0006^{* * *}$ & 0.0024 \\
\hline Income(-1) & - & - & - & - & $0.001^{* * *}$ & 0.0 \\
\hline Income(-2) & - & - & - & - & $0.0003^{*}$ & 0.05 \\
\hline Low paid & - & - & - & - & 0.22 & 0.17 \\
\hline Low paid(-1) & - & - & - & - & $-0.39^{* *}$ & 0.03 \\
\hline Low paid(-2) & - & - & - & - & - & - \\
\hline$R^{2}$ & 0.86 & - & 0.94 & - & 0.98 & - \\
\hline $\mathrm{F}$ bound test & $1.99^{*}$ & - & $0.64^{*}$ & - & $7.98^{*}$ & - \\
\hline
\end{tabular}


Table 7: Monetary policy rule: Germany - 2000-2008

\begin{tabular}{|c|c|c|c|c|c|c|}
\hline \multirow{2}{*}{$\begin{array}{l}\text { GER 2001-2008 } \\
\text { Gap variables }\end{array}$} & \multirow{2}{*}{$\begin{array}{l}\mathrm{R}^{*} \text { and } \\
\text { without } \\
\text { equality } \\
\text { Coefs. }\end{array}$} & \multirow{2}{*}{$\begin{array}{c}\begin{array}{c}\mathrm{y}^{*} \\
\text { in- }\end{array} \\
\text { P-value }\end{array}$} & \multicolumn{2}{|c|}{$\begin{array}{l}\mathrm{R}^{*} \text { and } \mathrm{y}^{*}+\text { in- } \\
\text { equality }\end{array}$} & \multicolumn{2}{|c|}{$\begin{array}{l}\mathrm{R}^{*} \text { and } \mathrm{y}^{*}+\text { in- } \\
\text { equality }+ \text { exoge- } \\
\text { nous variables }\end{array}$} \\
\hline & & & Coefs. & P-value & Coefs. & P-value \\
\hline Interest rate(-1) & $0.82^{* * *}$ & 0.0 & $1.60^{* * *}$ & 0.0 & 0.01 & 0.95 \\
\hline Interest rate(-2) & - & - & -0.68 & 0.0 & 0.43 & 0.15 \\
\hline Growth & 0.04 & 0.39 & -0.02 & 0.66 & $-0.14^{* *}$ & 0.02 \\
\hline Growth(-1) & $0.08^{*}$ & 0.07 & $0.25^{* * *}$ & 0.0002 & -0.04 & 0.56 \\
\hline Growth(-2) & 0.05 & 0.14 & - & - & $0.06^{* *}$ & 0.05 \\
\hline Inflation & $0.34^{*}$ & 0.08 & 0.13 & 0.59 & $-0.58^{*}$ & 0.09 \\
\hline Inflation(-1) & - & - & - & - & -0.94 & 0.09 \\
\hline Inflation(-2) & - & - & - & - & 0.53 & 0.31 \\
\hline Intercept & $0.94^{* *}$ & 0.02 & -0.46 & 0.23 & $940.93^{* * *}$ & 0.002 \\
\hline Ineq. variables & Coefs. & P-value & Coefs. & P-value & Coefs. & P-value \\
\hline Gini & - & - & - & - & 0.94 & 0.42 \\
\hline Gini(-1) & - & - & - & - & -0.97 & 0.53 \\
\hline Gini(-2) & - & - & - & - & -3.60 & 0.02 \\
\hline Palma & - & - & - & - & 0.36 & 0.17 \\
\hline Palma(-1) & - & - & - & - & $-0.72^{*}$ & 0.07 \\
\hline Palma(-2) & - & - & - & - & $0.40^{* *}$ & 0.05 \\
\hline Wealth & - & - & - & - & 0.08 & 0.73 \\
\hline Wealth(-1) & - & - & - & - & -0.19 & 0.50 \\
\hline Wealth(-2) & - & - & - & - & $-0.62^{* *}$ & 0.03 \\
\hline Gender & - & - & - & - & 0.11 & 0.92 \\
\hline Gender(-1) & - & - & - & - & 0.15 & 0.92 \\
\hline Gender(-2) & - & - & - & - & -1.44 & 0.32 \\
\hline Income & - & - & - & - & 0.05 & 0.13 \\
\hline Income $(-1)$ & - & - & - & - & 0.07 & 0.13 \\
\hline Income(-2) & - & - & - & - & $0.13^{* *}$ & 0.01 \\
\hline Low paid & - & - & - & - & 0.04 & 0.80 \\
\hline Low paid(-1) & - & - & - & - & -0.20 & 0.18 \\
\hline Low paid(-2) & - & - & - & - & - & - \\
\hline$R^{2}$ & 0.90 & - & 0.95 & - & 0.99 & - \\
\hline F bound test & $1.99^{*}$ & - & $2.23^{*}$ & - & $17.8^{*}$ & - \\
\hline
\end{tabular}


Table 8: Monetary policy rule : Germany - 2009-2019

\begin{tabular}{|c|c|c|c|c|c|c|}
\hline \multirow{2}{*}{$\begin{array}{l}\text { GER 2009-2019 } \\
\text { Gap variables }\end{array}$} & \multirow{2}{*}{$\begin{array}{l}\mathrm{R}^{*} \text { and } \\
\text { without } \\
\text { equality } \\
\text { Coefs. }\end{array}$} & \multirow{2}{*}{$\begin{array}{c}\begin{array}{c}\mathrm{y}^{*} \\
\text { in- }\end{array} \\
\text { P-value }\end{array}$} & \multicolumn{2}{|c|}{$\begin{array}{l}\mathrm{R}^{*} \text { and } \mathrm{y}^{*}+\text { in- } \\
\text { equality }\end{array}$} & \multicolumn{2}{|c|}{$\begin{array}{l}\mathrm{R}^{*} \text { and } \mathrm{y}^{*}+\text { in- } \\
\text { equality }+ \text { exoge- } \\
\text { nous variables }\end{array}$} \\
\hline & & & Coefs. & P-value & Coefs. & P-value \\
\hline Interest rate(-1) & $1.21^{* * *}$ & 0.0 & $1.24^{* * *}$ & 0.0 & $0.83^{* * *}$ & 0.0 \\
\hline Interest rate(-2) & $-0.38^{* * *}$ & 0.0027 & -0.38 & 0.0011 & $-0.27^{* *}$ & 0.05 \\
\hline Growth & 0.06 & 0.12 & -0.04 & 0.30 & -0.03 & 0.59 \\
\hline Growth(-1) & - & - & $0.12^{* * *}$ & 0.007 & 0.05 & 0.28 \\
\hline Growth(-2) & - & - & - & - & - & - \\
\hline Inflation & -0.52 & 0.28 & -0.22 & 0.65 & 0.13 & 0.80 \\
\hline Inflation(-1) & $1.53^{* *}$ & 0.02 & $1.39^{* *}$ & 0.02 & 0.81 & 0.18 \\
\hline Inflation(-2) & $-2.11^{* * *}$ & 0.0001 & $-2.12^{* * *}$ & 0.0001 & $-1.22^{* *}$ & 0.05 \\
\hline Intercept & $-1.06^{* * *}$ & 0.0039 & -1.50 & 0.0002 & -15.14 & 0.78 \\
\hline Ineq. variables & Coefs. & P-value & Coefs. & P-value & Coefs. & P-value \\
\hline Gini & - & - & - & - & $6.61^{* * *}$ & 0.0034 \\
\hline Gini(-1) & - & - & - & - & $-6.92^{* * *}$ & 0.001 \\
\hline Gini(-2) & - & - & - & - & - & - \\
\hline Palma & - & - & - & - & 0.005 & 0.98 \\
\hline Palma(-1) & - & - & - & - & $-0.65^{*}$ & 0.08 \\
\hline Palma(-2) & - & - & - & - & $0.66^{* *}$ & 0.01 \\
\hline Wealth & - & - & - & - & 0.04 & 0.69 \\
\hline Wealth(-1) & - & - & - & - & - & - \\
\hline Wealth(-2) & - & - & - & - & - & - \\
\hline Gender & - & - & - & - & 0.52 & 0.22 \\
\hline Gender(-1) & - & - & - & - & $-1.46^{* *}$ & 0.03 \\
\hline Gender(-2) & - & - & - & - & $0.86^{* *}$ & 0.02 \\
\hline Income & - & - & - & - & 0.03 & 0.61 \\
\hline Income $(-1)$ & - & - & - & - & $0.14^{* *}$ & 0.02 \\
\hline Income(-2) & - & - & - & - & - & - \\
\hline Low paid & - & - & - & - & -0.13 & 0.12 \\
\hline Low paid(-1) & - & - & - & - & $0.30^{* *}$ & 0.02 \\
\hline Low paid(-2) & - & - & - & - & $-0.21^{* * *}$ & 0.006 \\
\hline$R^{2}$ & 0.95 & - & 0.97 & - & 0.98 & - \\
\hline F bound test & 5.26 & - & 10.02 & - & 6.46 & - \\
\hline
\end{tabular}


Table 9: Monetary policy : Japan - 2000-2008

\begin{tabular}{|c|c|c|c|c|c|c|}
\hline \multirow{2}{*}{$\begin{array}{l}\text { JAP 2001-2008 } \\
\text { Gap variables }\end{array}$} & \multirow{2}{*}{$\begin{array}{l}\mathrm{R}^{*} \text { and } \\
\text { without } \\
\text { equality } \\
\text { Coefs. }\end{array}$} & \multirow{2}{*}{$\begin{array}{c}\begin{array}{c}\mathrm{y}^{*} \\
\text { in- }\end{array} \\
\text { P-value }\end{array}$} & \multicolumn{2}{|c|}{$\begin{array}{l}\mathrm{R}^{*} \text { and } \mathrm{y}^{*}+\text { in- } \\
\text { equality }\end{array}$} & \multicolumn{2}{|c|}{$\begin{array}{l}\mathrm{R}^{*} \text { and } \mathrm{y}^{*}+\text { in- } \\
\text { equality }+ \text { exoge- } \\
\text { nous variables }\end{array}$} \\
\hline & & & Coefs. & P-value & Coefs. & P-value \\
\hline Interest rate(-1) & $1.34^{* * *}$ & 0.0 & $1.30^{* * *}$ & 0.0 & $0.88^{* *}$ & 0.01 \\
\hline Interest rate(-2) & $-0.52^{* *}$ & 0.02 & -0.56 & 0.0017 & $-0.74^{* * *}$ & 0.007 \\
\hline Growth & -0.73 & 0.28 & -0.08 & 0.24 & -0.02 & 0.77 \\
\hline Growth(-1) & - & - & $-0.16^{*}$ & 0.047 & $-0.18^{* * *}$ & 0.008 \\
\hline Growth(-2) & - & - & - & - & -0.07 & 0.25 \\
\hline Inflation & $2.54^{* *}$ & 0.04 & $3.00^{*}$ & 0.07 & -2.56 & 0.19 \\
\hline Inflation(-1) & -0.70 & 0.64 & $-2.98^{*}$ & 0.08 & 2.26 & 0.33 \\
\hline Inflation(-2) & -1.65 & 0.19 & - & - & $4.79^{* *}$ & 0.03 \\
\hline Intercept & 0.18 & 0.14 & 0.23 & 0.86 & $-732.38^{* *}$ & 0.01 \\
\hline Ineq. variables & Coefs. & P-value & Coefs. & P-value & Coefs. & P-value \\
\hline Gini & - & - & - & - & $10.36^{* *}$ & 0.03 \\
\hline Gini(-1) & - & - & - & - & -3.68 & 0.24 \\
\hline Gini(-2) & - & - & - & - & - & - \\
\hline Palma & - & - & - & - & $-0.90^{* *}$ & 0.03 \\
\hline Palma(-1) & - & - & - & - & - & - \\
\hline Palma(-2) & - & - & - & - & - & - \\
\hline Wealth & - & - & - & - & $-1.31^{* *}$ & 0.02 \\
\hline Wealth(-1) & - & - & - & - & - & - \\
\hline Wealth(-2) & - & - & - & - & - & - \\
\hline Gender & - & - & - & - & -2.21 & 0.43 \\
\hline Gender(-1) & - & - & - & - & $-6.09^{* *}$ & 0.05 \\
\hline Gender(-2) & - & - & - & - & $12.43^{* * *}$ & 0.001 \\
\hline Income & - & - & - & - & - & - \\
\hline Income $(-1)$ & - & - & - & - & - & - \\
\hline Income(-2) & - & - & - & - & - & - \\
\hline Low paid & - & - & - & - & $1.82^{* *}$ & 0.01 \\
\hline Low paid(-1) & - & - & - & - & -0.81 & 0.23 \\
\hline Low paid(-2) & - & - & - & - & 0.68 & 0.12 \\
\hline$R^{2}$ & 0.87 & - & 0.84 & - & 0.97 & - \\
\hline $\mathrm{F}$ bound test & $1.43^{*}$ & - & $4.16^{*}$ & - & $7.36^{*}$ & - \\
\hline
\end{tabular}


Table 10: Monetary policy rule : Japan - 2009-2019

\begin{tabular}{|c|c|c|c|c|c|c|}
\hline \multirow{2}{*}{$\begin{array}{l}\text { JAP 2009-2019 } \\
\text { Gap variables }\end{array}$} & \multirow{2}{*}{$\begin{array}{l}\mathrm{R}^{*} \quad \text { and } \\
\text { without } \\
\text { equality } \\
\text { Coefs. }\end{array}$} & \multirow{2}{*}{$\begin{array}{l}\mathrm{y}^{*} \\
\text { in- } \\
\text { P-value }\end{array}$} & \multicolumn{2}{|c|}{$\begin{array}{l}\mathrm{R}^{*} \text { and } \mathrm{y}^{*}+\text { in- } \\
\text { equality }\end{array}$} & \multicolumn{2}{|c|}{$\begin{array}{l}\mathrm{R}^{*} \text { and } \mathrm{y}^{*}+\text { in- } \\
\text { equality }+ \text { exoge- } \\
\text { nous variables }\end{array}$} \\
\hline & & & Coefs. & P-value & Coefs. & P-value \\
\hline Interest rate(-1) & $1.49^{* * *}$ & 0.0 & $1.36^{* * *}$ & 0.0 & $0.55^{* * *}$ & 0.0036 \\
\hline Interest rate(-2) & $-0.56^{* * *}$ & 0.003 & $-0.47^{* * *}$ & 0.008 & $-0.85^{* * *}$ & 0.0 \\
\hline Growth & -0.07 & 0.84 & -0.06 & 0.34 & $0.27^{* * *}$ & 0.003 \\
\hline Growth(-1) & 0.42 & 0.26 & $-0.17^{* *}$ & 0.013 & $0.17^{* *}$ & 0.05 \\
\hline Growth(-2) & $-0.64^{* *}$ & 0.02 & - & - & 0.08 & 0.17 \\
\hline Inflation & 0.25 & 0.32 & $1.49^{*}$ & 0.09 & 0.26 & 0.80 \\
\hline Inflation(-1) & - & - & -1.37 & 0.11 & $-3.05^{* * *}$ & 0.0013 \\
\hline Inflation(-2) & - & - & - & - & $1.02^{*}$ & 0.10 \\
\hline Intercept & 0.60 & 0.13 & -0.01 & 0.99 & $326.65^{* * *}$ & 0.0035 \\
\hline Ineq. variables & Coefs. & P-value & Coefs. & P-value & Coefs. & P-value \\
\hline Gini & - & - & - & - & -7.76 & 0.03 \\
\hline Gini(-1) & - & - & - & - & 9.35 & 0.14 \\
\hline Gini(-2) & - & - & - & - & $-14.76^{* * *}$ & 0.008 \\
\hline Palma & - & - & - & - & $0.87^{* *}$ & 0.012 \\
\hline Palma(-1) & - & - & - & - & - & - \\
\hline Palma(-2) & - & - & - & - & & \\
\hline Wealth & - & - & - & - & -0.16 & 0.62 \\
\hline Wealth(-1) & - & - & - & - & - & - \\
\hline Wealth(-2) & - & - & - & - & - & - \\
\hline Gender & - & - & - & - & -1.33 & 0.41 \\
\hline Gender(-1) & - & - & - & - & 0.60 & 0.83 \\
\hline Gender(-2) & - & - & - & - & 2.14 & 0.22 \\
\hline Income & - & - & - & - & - & - \\
\hline Income(-1) & - & - & - & - & - & - \\
\hline Income(-2) & - & - & - & - & - & - \\
\hline Low paid & - & - & - & - & -0.20 & 0.19 \\
\hline Low paid(-1) & - & - & - & - & $-0.37^{* *}$ & 0.03 \\
\hline Low paid(-2) & - & - & - & - & $-0.33^{*}$ & 0.08 \\
\hline$R^{2}$ & 0.94 & - & 0.88 & - & 0.97 & - \\
\hline F bound test & 2.01 & - & 2.54 & - & $8.17^{*}$ & - \\
\hline
\end{tabular}




\section{Appendix A Data sources and estimation results}

Table 11: Sources and data

\begin{tabular}{|c|c|c|}
\hline Variable & Description & Source \\
\hline$y_{t}$ & $\begin{array}{l}\text { Real GDP (per-capita). We take the loga- } \\
\text { rithm. }\end{array}$ & OECD Database \\
\hline$r_{t}$ & $\begin{array}{l}\text { Short-term real interest rate (nominal minus } \\
\text { headline inflation. We take the shadow nom- } \\
\text { inal rate }\end{array}$ & $\begin{array}{l}\text { OECD Database for inflation. } \\
\text { CB of New Zealand for shadow } \\
\text { rate }\end{array}$ \\
\hline GINI & $\begin{array}{l}\text { Gini (disposable income post taxes Data and } \\
\text { transfers). Data are annual and transformed } \\
\text { into quarterly data Original data end in } 2017 \text {. } \\
\text { We replicate the } 2017 \text { values for } 2018 \text { and } \\
2019 \text {. }\end{array}$ & $\begin{array}{l}\text { OECD income distribution } \\
\text { database }\end{array}$ \\
\hline Income disparities & $\begin{array}{l}\text { Palma ratio: Share of top } 10 \% \text { over bottom } \\
40 \% \text { (income distribution) }\end{array}$ & $\begin{array}{l}\text { OECD income distribution } \\
\text { database }\end{array}$ \\
\hline Wealth inequalities & $\begin{array}{l}\text { Total wealth share of top } 10 \% \text { of wealth / to- } \\
\text { tal wealth share of bottom } 60 \% \text { of wealth }\end{array}$ & $\begin{array}{l}\text { OECD Social and Welfare Statis- } \\
\text { tics and for Households' finan- } \\
\text { cial and non-financial assets, } \\
\text { OECD National Accounts Data }\end{array}$ \\
\hline $\begin{array}{l}\text { Family labour sta- } \\
\text { tus }\end{array}$ & $\begin{array}{l}\text { Ratio of perc. of children living in family } \\
\text { where all adults work and perc. of children } \\
\text { living in family where only one adult works. } \\
\text { Some data start in } 2005 \text {. For the years } 2000- \\
2004 \text {, we replicate the data of } 2005 \text {. }\end{array}$ & $\begin{array}{l}\text { OECD Social and Welfare Statis- } \\
\text { tics }\end{array}$ \\
\hline$\pi_{t}$ & $\begin{array}{l}\text { Core inflation. Consumer prices, all foods } \\
\text { non-food, non-energy }\end{array}$ & OECD Stat \\
\hline Imported inflation & $\begin{array}{l}\text { G20 CPI all items. We compute core using } \\
\text { HP filter and we divide the results by core } \\
\text { inflation defined above. }\end{array}$ & OECD Stat \\
\hline Oil prices & $\begin{array}{l}\text { Crude oil import prices. We compute core as } \\
\text { the HP filter trend calculated on the index } \\
\text { and we divide the result by domestic core } \\
\text { inflation. }\end{array}$ & OECD Data \\
\hline Gender gap & $\begin{array}{l}\text { Labour force participation rate (ratio of men } \\
\text { over women). Data are annual and converted } \\
\text { in quarterly data. }\end{array}$ & $\begin{array}{l}\text { OECD Social and Welfare Wel- } \\
\text { fare Statistics Statistics }\end{array}$ \\
\hline $\begin{array}{l}\text { Labour income } \\
\text { share growth rate } \\
\text { minus productiv- } \\
\text { ity growth rate }\end{array}$ & $\begin{array}{l}\text { Labour income share ratios: Original data } \\
\text { are annual and converted to quarterly data. } \\
\text { Productivity is measured by GDP per person } \\
\text { employed quarterly change). }\end{array}$ & OECD Data on unit labor cost \\
\hline Low pay workers & $\begin{array}{l}\text { Share of workers earning less than two-thirds } \\
\text { of median earnings (full-time employees). } \\
\text { Original data are annual and converted to } \\
\text { quarterly data }\end{array}$ & OECD Wage levels. \\
\hline
\end{tabular}




\section{Appendix B A simple model linking labour income share and prices in AS equation}

We propose a stylized model in which inequalities related to changes in the distribution of income shares is shown to affect the dynamics of inflation in AS equation.

Nominal wage rate is set by employees, based on their expectations of future price level. Consumer prices are a weighted average of producer and foreign prices:

$$
\left(1+T_{t}^{d}\right) W_{t}^{s}=\left(1+T_{t}^{v}\right) P_{c t}^{e}, P_{c t}=P_{t}^{1-\phi_{t}}\left(P_{t}^{*} E_{t}\right)^{\phi_{t}},
$$

where $W_{t}^{s}$ is the nominal wage rate, $T_{t}^{d}$ and $T_{t}^{v}$ are tax rates on respectively wages (income or payroll tax) and consumption goods (VAT). $P_{c t}^{e}$ is the expected level of consumer prices, $E_{t}$ is the nominal exchange rate. $\phi_{t}$ is the share of foreign goods in the consumer's basket of consumption. $P_{t}$ and $P_{t}^{*}$ are producer prices in the domestic and foreign countries.

Using a log-linearized form, the real wage rate depends on fiscal wedge and on the expected level of consumer prices (small letter are log):

$$
w_{t}^{s}=\left(t_{t}^{v}-t_{t}^{d}\right)+p_{c t}^{e}, p_{c t}-p_{t}=\phi_{t}+\theta_{t}, \theta_{t}=p_{t}^{*}-p_{t}+e_{t}
$$

$\theta_{t}$ is the real exchange rate defined as the ratio of foreign prices $p_{t}^{*}$ expressed in units of domestic currency ( $e_{t}$ is the nominal exchange rate) to domestic prices $p_{t}$. The weighting coefficient $\phi_{t}$ is assumed to be variable over time. It can be considered as a proxy for the degree of pass-through of foreign prices into domestic prices.

Firms produce $Y_{t}$ with labor (the employment level is $N_{t}$ ). The production function- in logarithm - is written $Y_{t}=N_{t}^{\gamma_{t}}$, where $\gamma_{t}$ denotes the share of wages out of national income (wage share). For simplicity we assume that capital stock is fixed.

The first-order condition of profit maximization leads the firms to choose its optimal level of employment. This choice implies

$$
p_{t}-p_{c t}^{e}=-\ln \gamma_{t}+\left(t_{t}^{v}-t_{t}^{d}\right)+y_{t}
$$

where $y_{t}$ is per-capita GDP (in logarithm). Inflation expectations are defined as a weighted average of an anchor price and past consumer prices. In logarithms, we write:

$$
p_{c t}^{e}=(1-\lambda) \bar{p}_{c t}+\lambda D_{\pi}^{p_{\pi}}(L) p_{c t}, \quad 0<\lambda<1
$$


Defining CPI inflation $\pi_{c t}=\Delta p_{c t}$, total inflation $\pi_{t}=\Delta p_{t}$, expected inflation $\pi_{c t}^{e}=p_{c t}^{e}$, and assuming that tax rates are constant, we obtain the following short-term aggregate supply curve:

$$
\begin{gathered}
\pi_{c t}=\pi_{c t}^{e}+\Delta \ln \left(\gamma_{t}\right)+\Delta y_{t}+\epsilon_{t}^{\pi}, \\
\pi_{c t}^{e}=(1-\lambda) \bar{\pi}_{c t}+\lambda D_{\pi}^{p_{\pi}}(L) \pi_{c t}, \quad 0<\gamma_{t}<1 .
\end{gathered}
$$

Equation (2) is obtained by assuming extrapolative expectations, $\lambda=1$ in Equation (A6) and by taking into account the cyclical nature of labor productivity dynamics (See Bhaumik (2011) for empirical evidence in the industrialized countries). Further changes in the labourincome share is equivalent to changes in the gap between the growth rate of wages and productivity. Both have been shown to be linked to factors of inequalities (for instance, gender gap) and international environment (here imported inflation and energy prices to account for possible substitution between labour and factors of production that are energybased). 


\section{Appendix C State-space representation of the model}

$$
\begin{gathered}
X_{t}=A X_{t-1}+\zeta_{t}+F_{t} \eta_{t}: \text { state equation } \\
Y_{t}=\mu_{t}+C_{t}^{T} X_{t}+G_{t} V_{t}: \quad \text { measurement equation }
\end{gathered}
$$

with the following definitions of the variables

$$
\underset{(7 \times 1)}{\mathrm{X}_{\mathrm{t}}}=\left(\begin{array}{c}
y_{t}^{*} \\
y_{t-1}^{*} \\
y_{t-2}^{*} \\
g_{t} \\
g_{t-1} \\
s_{t} \\
s_{t-1}
\end{array}\right), \underset{(7 \times 7)}{\mathrm{A}}=\left(\begin{array}{ccccccc}
1 & 0 & 0 & 1 & 0 & 0 & 0 \\
1 & 0 & 0 & 0 & 0 & 0 & 0 \\
0 & 1 & 0 & 0 & 0 & 0 & 0 \\
0 & 0 & 0 & 1 & 0 & 0 & 0 \\
0 & 0 & 0 & 1 & 0 & 0 & 0 \\
0 & 0 & 0 & 0 & 0 & \delta_{g} & 0 \\
0 & 0 & 0 & 0 & 0 & 1 & 0
\end{array}\right), \underset{(7 \times 1)}{\zeta_{t}}=\left(\begin{array}{l}
0 \\
0 \\
0 \\
0 \\
0 \\
\bar{g} \\
0 \\
0
\end{array}\right),
$$

$$
\underset{(3 \times 1)}{\eta_{t}}=\left(\begin{array}{c}
\epsilon_{t}^{y^{*}} \\
\epsilon_{t}^{g} \\
\epsilon_{t}^{s}
\end{array}\right), \underset{(7 \times 3)}{\mathrm{F}_{\mathrm{t}}}=\left(\begin{array}{ccc}
\sigma_{y^{*}} & \sigma_{g} & 0 \\
0 & 0 & 0 \\
0 & 0 & 0 \\
0 & \sigma_{g} & 0 \\
0 & 0 & 0 \\
0 & 0 & \sigma_{s} \\
0 & 0 & 0
\end{array}\right), \underset{(2 \times 1)}{\mathrm{Y}_{\mathrm{t}}}=\left(\begin{array}{c}
y_{t} \\
\pi_{t}
\end{array}\right)
$$


$\underset{(2 \times 14)}{\mu_{t}}=\left(\begin{array}{ccc}\boldsymbol{A} \boldsymbol{A} & \mathbf{0} & 0 \\ b_{1} & \mathbf{0} & \boldsymbol{B} \boldsymbol{B}\end{array}\right)\left(\begin{array}{c}y_{t-1} \\ y_{t-2} \\ r_{t-3} \\ r_{t-4} \\ 1 \\ \boldsymbol{\kappa}_{t} \\ \boldsymbol{Z}_{t} \\ \boldsymbol{W}_{t}\end{array}\right), \underset{(8 \times 1)}{\boldsymbol{A} A^{T}}=\left(\begin{array}{c}a_{y}^{0} \\ a_{y}^{1} \\ a^{r} 2 \\ a^{r} 2 \\ a_{4} \\ a_{\text {Gini }}^{1} \\ a_{\text {Palma }}^{1} \\ a_{\text {wealth }}^{1}\end{array}\right), \underset{(5 \times 1)}{\boldsymbol{B} \boldsymbol{B}^{T}}=\left(\begin{array}{c}b_{\text {oil }}^{1} \\ b_{\text {imp }}^{1} \\ b_{\text {gender }}^{1} \\ b_{\text {wage }}^{1} \\ b_{\text {low }}^{1}\end{array}\right)$

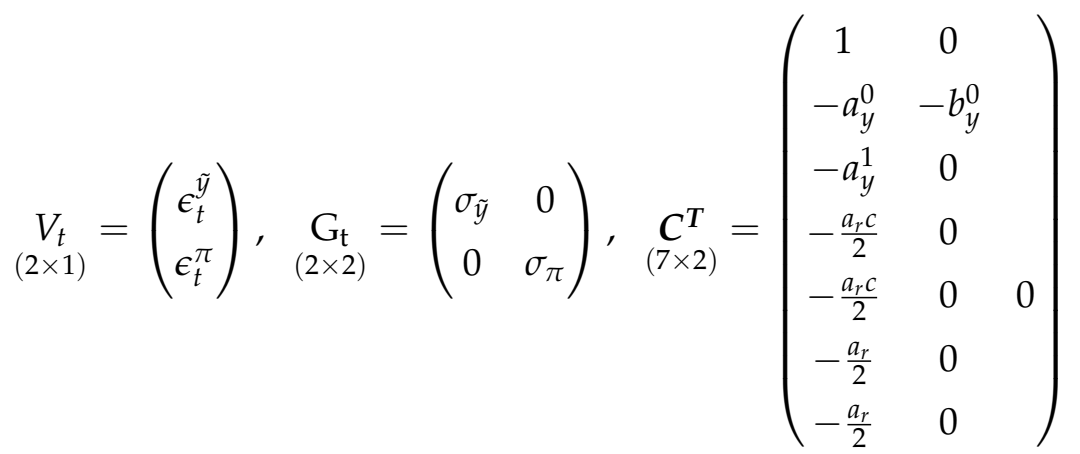

$\underset{(1 \times 3)}{\boldsymbol{Z}^{T}}=\left(\begin{array}{c}\text { Gini }_{t-1} \\ \text { Palma }_{t-1} \\ \text { Wealth }_{t-1}\end{array}\right), \underset{(1 \times 2)}{\underset{\boldsymbol{\kappa}}{T}}=\left(\begin{array}{c}\text { poil }_{t-1} \\ \text { pimp }_{t-1}\end{array}\right), \underset{(1 \times 3)}{\boldsymbol{W}^{T}}=\left(\begin{array}{c}\text { Gender }_{t-1} \\ \text { wages }_{t-1} \\ \text { Low }_{t-1}\end{array}\right)$. 


\section{Appendix D Figures}

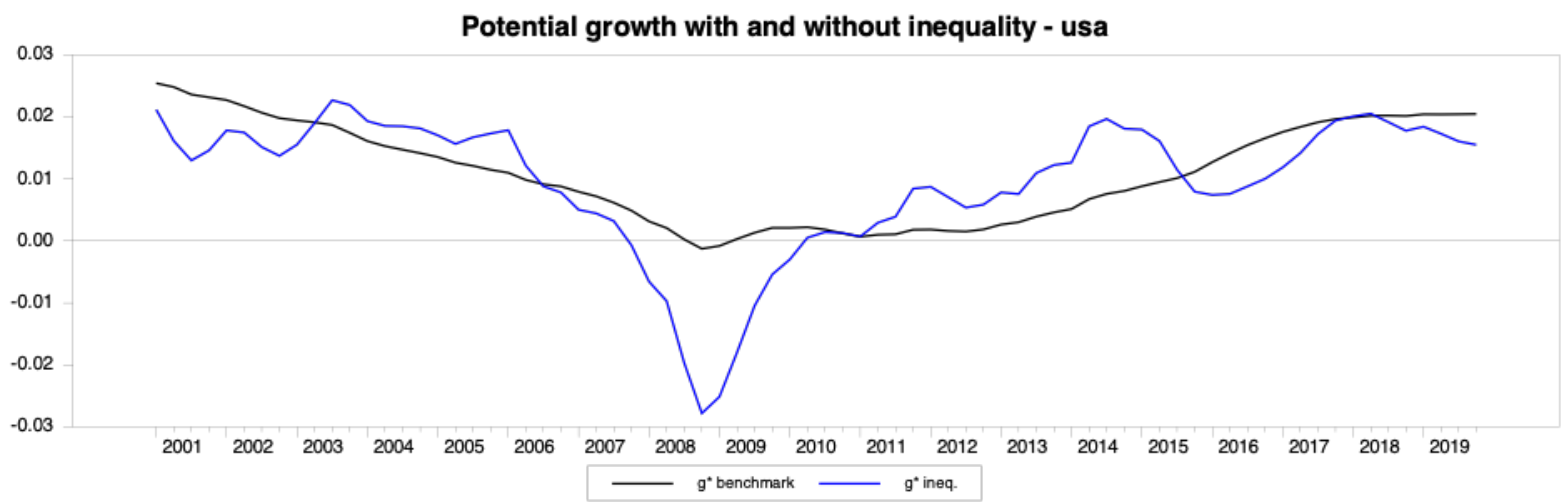

Figure 1: Time path of potential growth for the United States

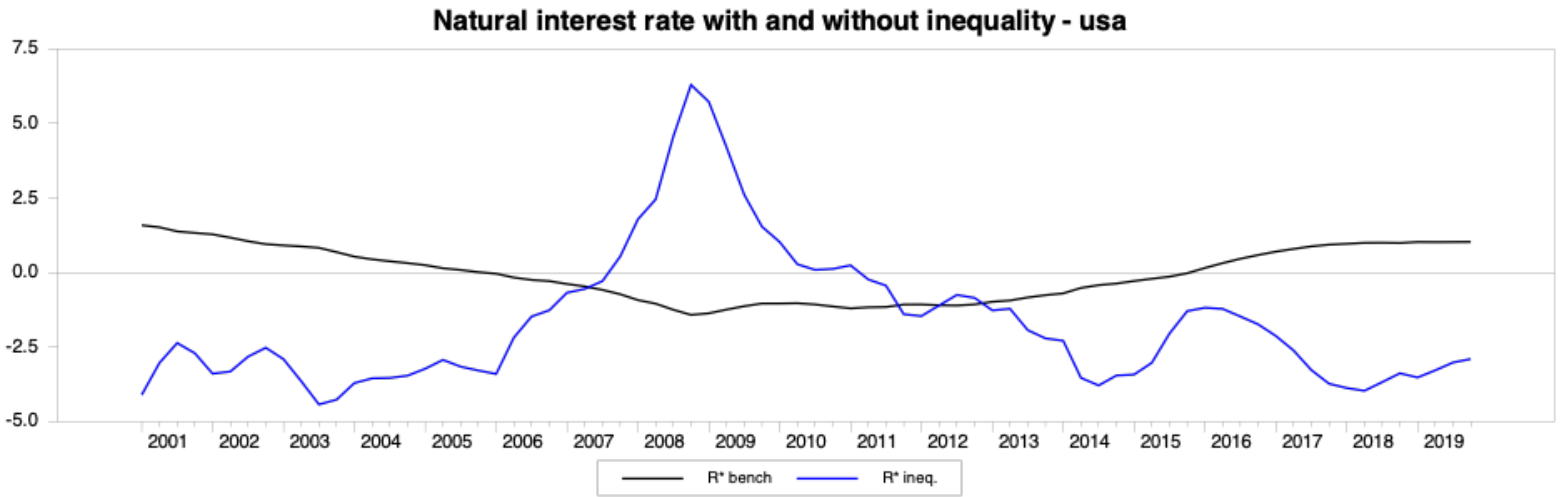

Figure 2: Time path of the natural interest rate for the United States

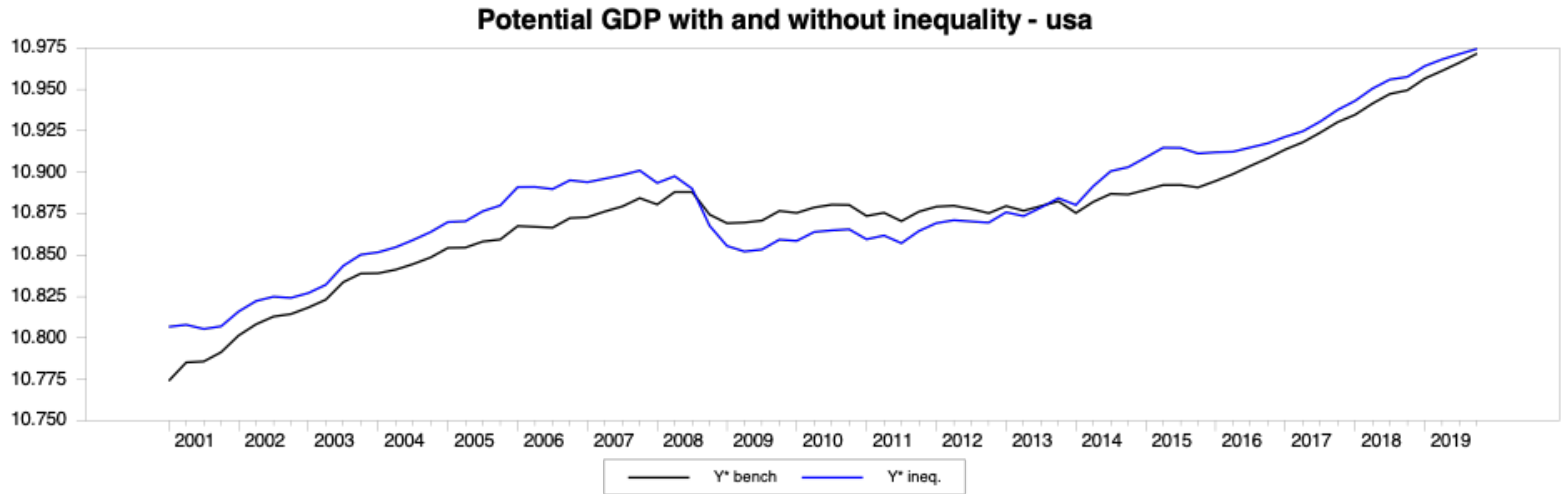

Figure 3: Time path of potential GDP for the United States 


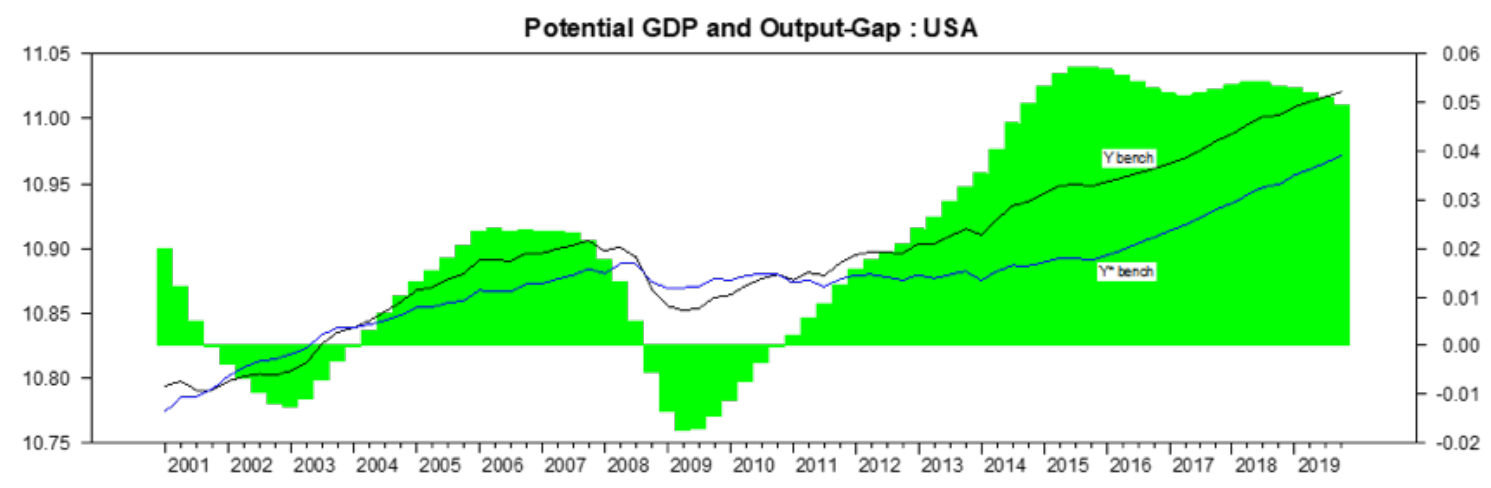

(a) Time path of output gap for the United States

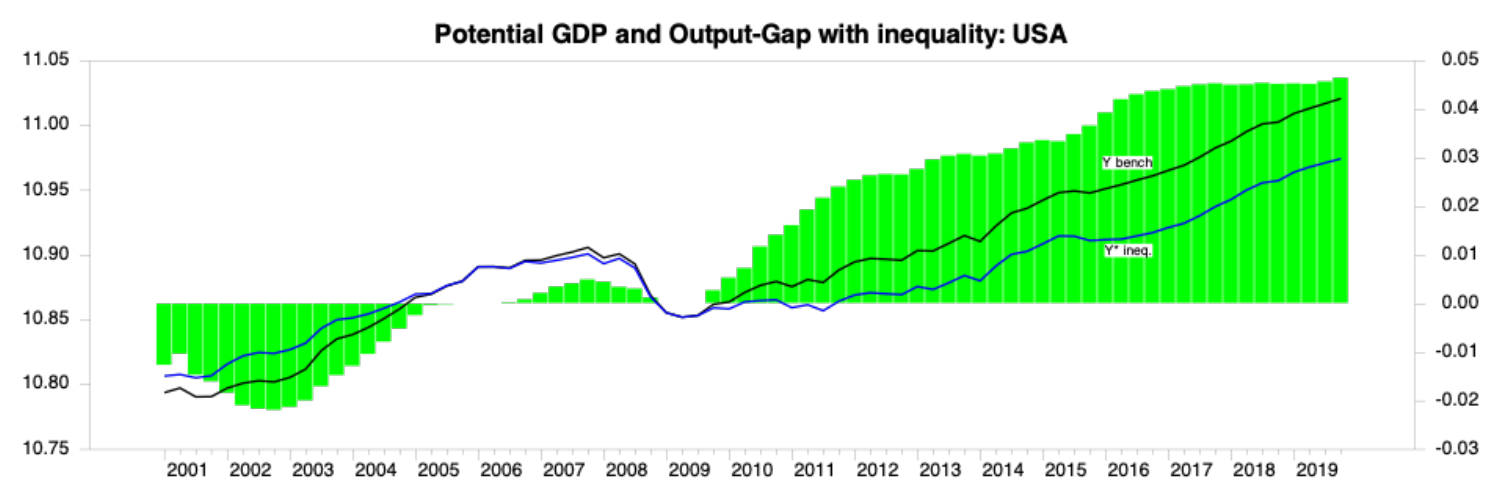

(b) Time path of output gap accounting for inequality. United States

Figure 4: Output gap with and without inequality. United States. 
$200120022003200420052006 \quad 200720082009201020112012 \quad 2013201420152016201720182019$ - $g^{*}$ benchmark $\longrightarrow g^{*}$ ineq.

Figure 5: Time path of potential growth for Germany

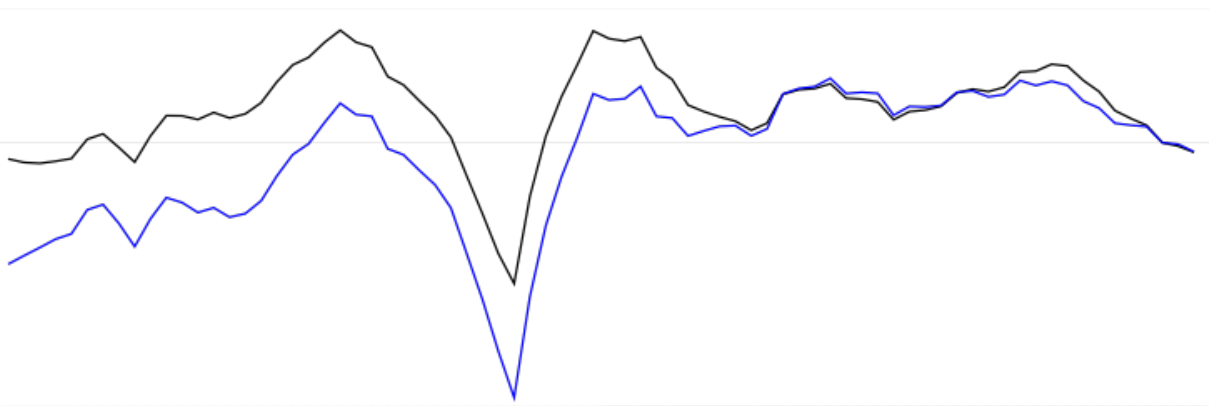

Natural interest rate with and without inequality - Germany

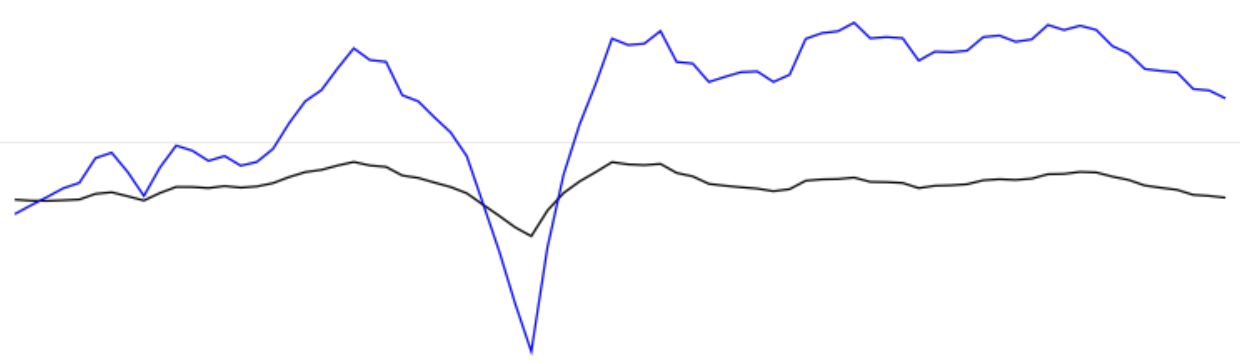

$200120022003 \quad 200420052006 \quad 2007 \quad 2008 \quad 20092010 \quad 2011 \quad 2012 \quad 2013 \quad 2014 \quad 20152016 \quad 2017 \quad 20182019$ - $R^{*}$ bench $\quad R^{*}$ ineq.

Figure 6: Time path of the natural interest rate for Germany

Potential GDP with and without inequality - Germany

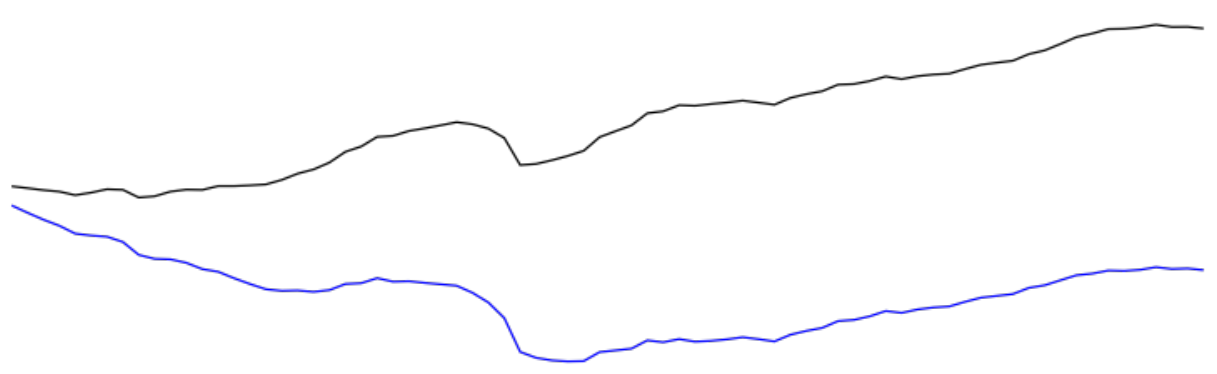

$\begin{array}{lllllllllllllllllll}2001 & 2002 & 2003 & 2004 & 2005 & 2006 & 2007 & 2008 & 2009 & 2010 & 2011 & 2012 & 2013 & 2014 & 2015 & 2016 & 2017 & 2018 & 2019\end{array}$

Figure 7: Time path of potential GDP for Germany 


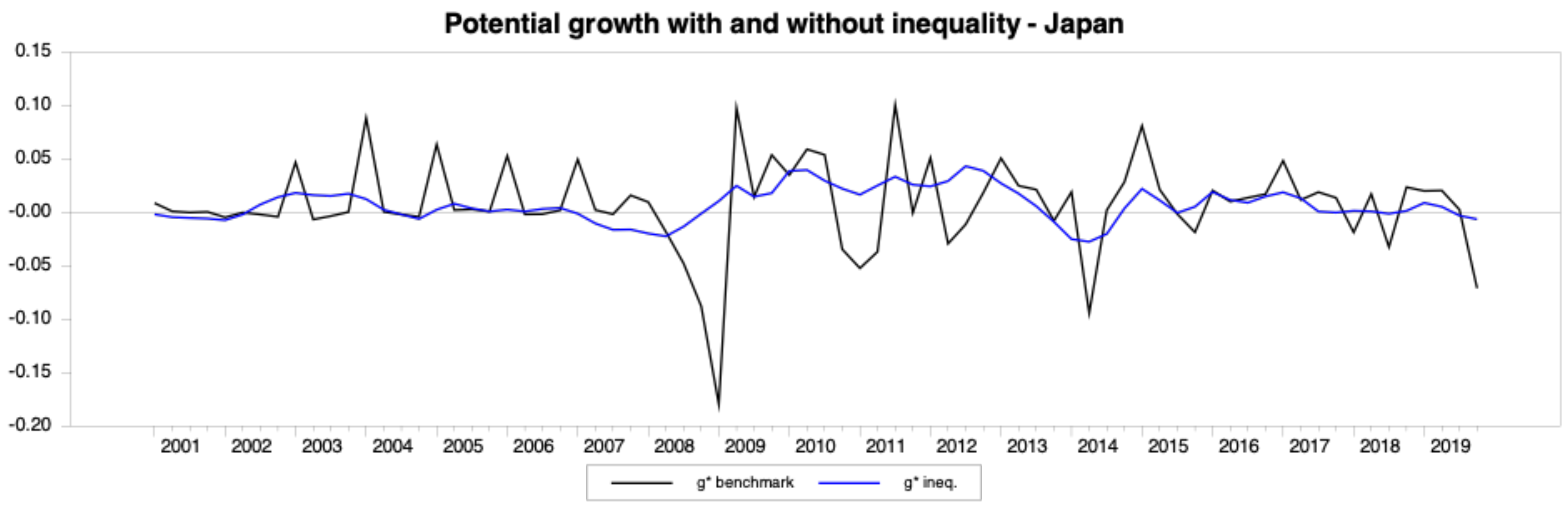

Figure 8: Time path of potential growth for Japan

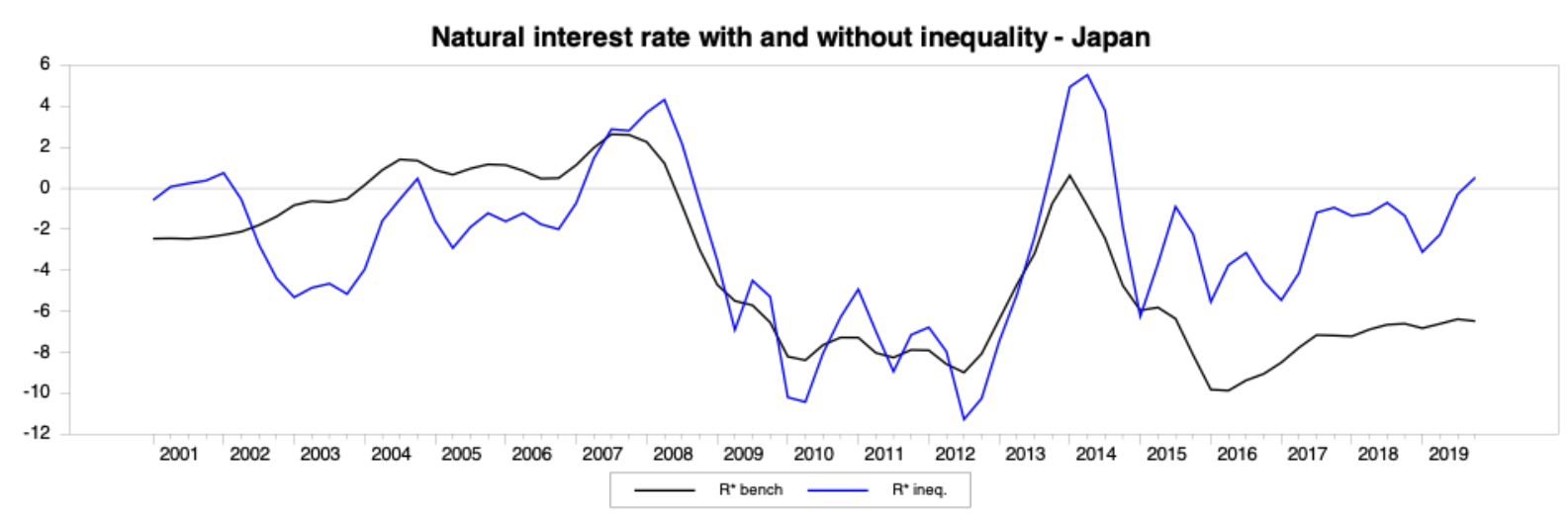

Figure 9: Time path of the natural interest rate for Japan

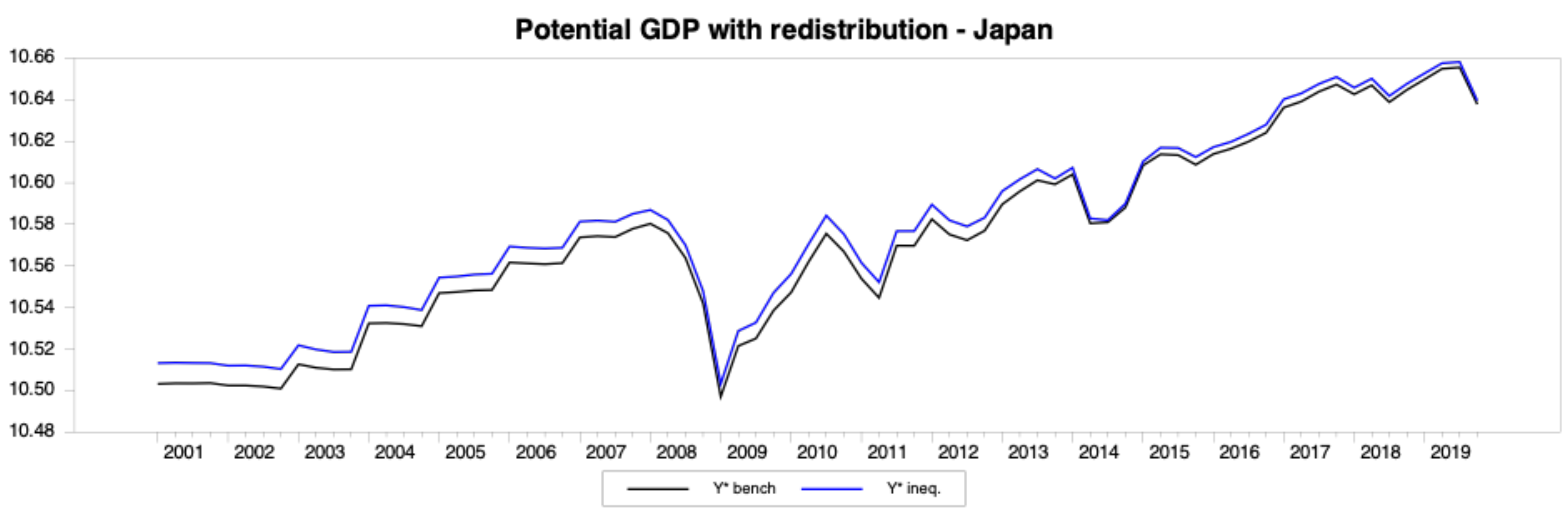

Figure 10: Time path of potential GDP for Japan 


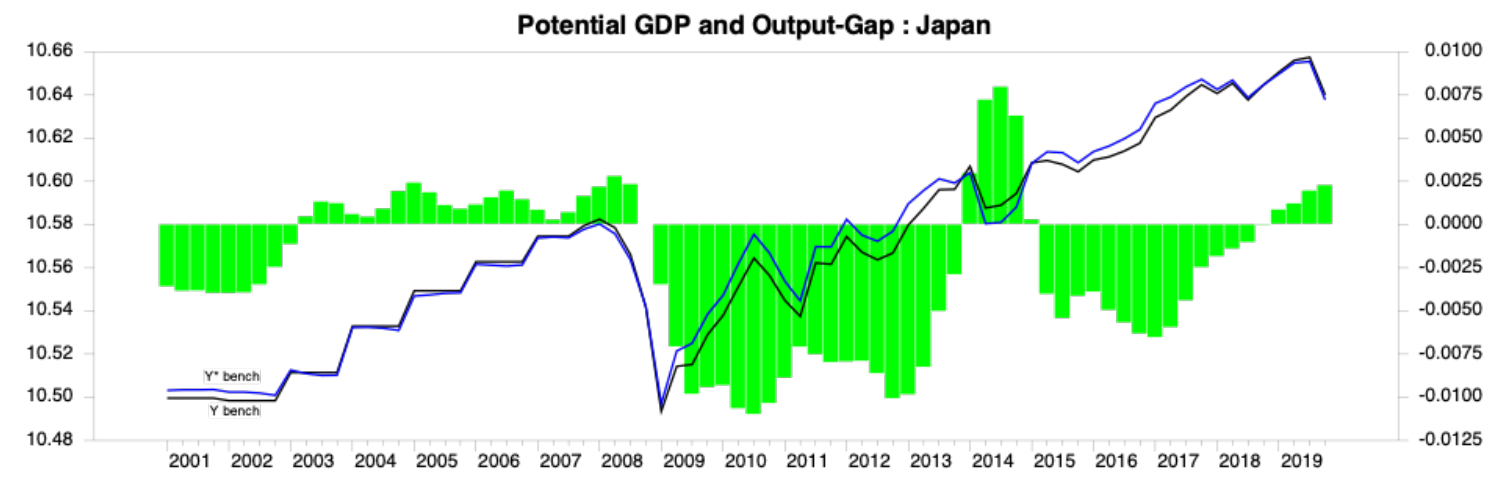

(a) Time path of output gap for Japan

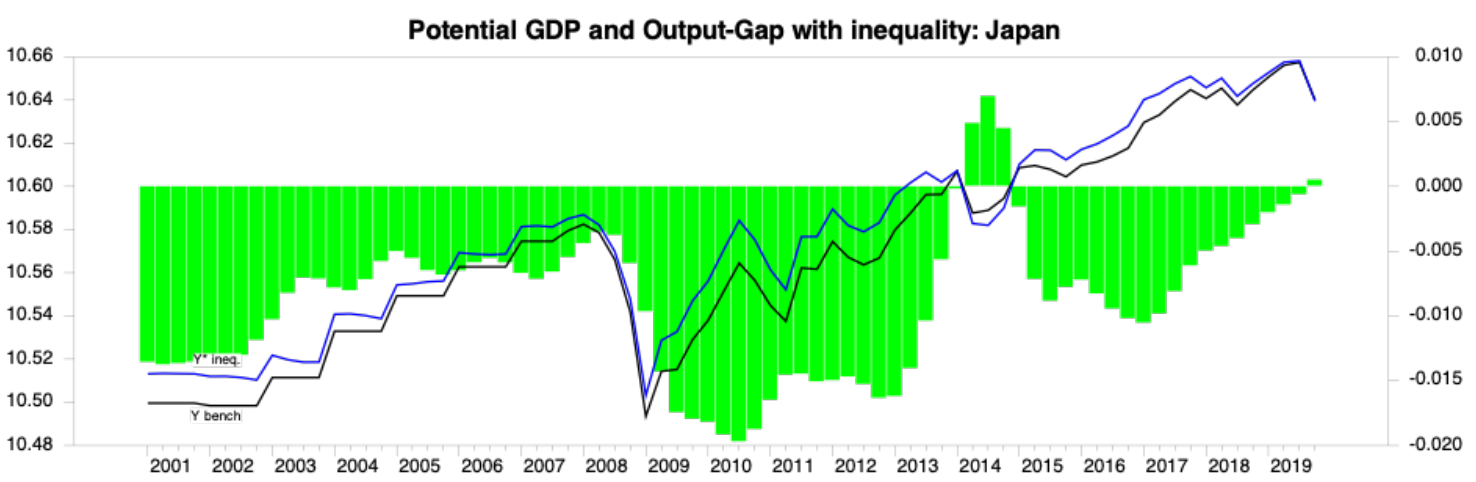

(b) Time path of output gap accounting for inequality. Japan

Figure 11: Output gap with and without inequality. Japan. 